\title{
TRADITIONAL KNOWLEDGE BASED INVENTORY OF WILD PLANTS OF WATALA NATIONAL PARK AND ALLIED VILLAGES FROM BHIMBER DISTRICT, AZAD JAMMU AND KASHMIR, PAKISTAN
}

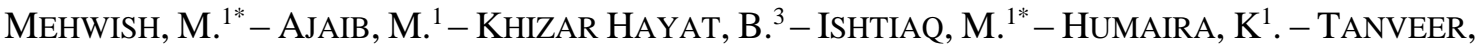 \\ H. ${ }^{1}-$ GHANI, A. ${ }^{2}-$ WAHEEDA, M. ${ }^{1}$ \\ ${ }^{1}$ Department of Botany, Mirpur University of Science \& Technology (MUST), Mirpur 10250 \\ (AJK), Pakistan \\ ${ }^{2}$ Department of Botany, University of Sargodha, Sargodha, Pakistan \\ ${ }^{3}$ Department of Botany, University of Gujrat, Gujrat, Pakistan \\ *Corresponding authors \\ e-mail: mehwishmaqbool11@gmail.com \\ (Received 26 ${ }^{\text {th }}$ Apr 2019; accepted $11^{\text {th }}$ Jul 2019)
}

\begin{abstract}
An ethnobotanical (EB) research was conducted on the wild plants of Watala National Park (WNP) and allied villages of Barnala, District Bhimber, Azad Jammu and Kashmir (AJK), Pakistan. EB data have been collected by questionnaire method employing structured and semi-structured interviews. A total of 79 interviewees (47 male, 32 female) having age 25-65 years were included in the EB study. 92 plant species of 37 families were studied and the obtained data were compiled in an inventory form consisting of ethnomedicinal (EM) use, parts used, mode of application and EB use. For validation of EM data of plants different microstatistical tools like frequency of citation (FC), relative frequencies of citation (RFC), use value (UV), fidelity level (FL) and informant consensus factor (ICF) were used. Direct matrix ranking (DMR) and priority ranking (PR) were applied on EB data for quantitative analysis to find multiple use forms of plant(s) and calculate biotic threats for the plants. Study results depicted that FC ranged 59 to 11 , RFC was 0.75 to 0.14 and UV was between 0.82 and 0.15 . Leaves were the most frequently used $(31 \%)$ part of plants and powder form (25\%) was the most commonly used form. The highest FL was found for Senegalia modesta species (100\%) and diseases such as fever, flu, headache, bronchitis and cough ranked first (0.94) in ICF analysis. DMR results showed that Senegalia modesta was the first regarding multifarious use. Fuel wood cutting and fire burning were top two threats for the flora of the area. Due to anthropogenic pressure and climatic dynamics plants of the area are under severe threats and there is urgent need to conserve the flora of WNP, District Bhimber for future generations and to introduce sustainable applications.
\end{abstract}

Keywords: traditional ethnobotanical knowledge, informant consensus factor, relative frequency, folklore therapeutics, green drugs, conservation status

\section{Introduction}

Plants have been used by man for his sustenance on the planet. Wild plants had been part and parcel of daily needs of people inhabiting different rural parts of the world. Plants provide fundamental necessities of daily life because rural communities are primarily dependent on wild plant resources for fulfilling the needs of their life (Ishtiaq and Khan, 2008).

Ethnobotany (EB) is discipline of botany in which we study the native people's relationship with indigenous flora of the area and it encompasses the biocultural diversity of plants and human sociological paradigms (Harshberger, 1895; Ishtiaq et al., 2016). It was demonstrated that ethnobotany and ecology are interlinked with each other and this 
intermingling of two or more disciplines give ecoethnobotany (EEB) discipline which give significant importance of plants in the life of indigenous communities and ecosystem sustainability (Jones, 1941; Ford, 1978; Ajaib et al., 2014a). EB is the study of direct interaction between human beings and the flora through their coinciding biodiversity and civilization/cultural diversity in the form of index of biocultural diversity (IBCD) which describes this interdependence (Pie, 1995; Ahmad et al., 2008; Ishtiaq et al., 2013a). Plants perform variety of keystone roles in our daily life such as plants provide food, fodder, medicines, shelter, cosmetics, shadow, hedging and fencing, dyes, fuel and aesthetics in the form of ornamental taxa. They have a great role in environmental functions such as stabilizing soil, recycling of nutrients, photosynthesis, protecting water drainage areas and help to restraint rainfall through the process of transpiration (Mehmood et al., 2012; Naseem et al., 2018). Plants are also involved in the manufacturing of different phytochemicals also called secondary metabolites which are potential sources of disease treatment through drug discovery and development process (Ajaib et al., 2014b).

Pakistan has rich and abundant plant resources and nearly more than 6000 plants have been reported, particularly more than 2000 species are known as medicinal plants (MPs) being used in the cure of many diseases by local communities of the country (Ali et al., 2001; Umair et al., 2017; Sher et al., 2016). The plants have been playing pivotal role in coping the basic needs of rural communities in various parts of Pakistan and AJK (Ishtiaq et al., 2013b). The indigenous people of mountainous and remote areas of AJK had been dependent primarily on local plants for obtaining needs of life such as food, fodder, shelter and ethnomedicines. The information about plants regarding their role as EMs and other EB necessities is very helpful to ecologists, pharmacologists, taxonomists, watershed and wild life managers. These are documented to conserve the civilization norms and folklore traditions of various ethnic groups and areas and describe how plants are inevitable in the prosperity of indigenous communities of the area (Ishtiaq et al., 2012, 2013a; Ajaib et al., 2014b; Chassagne et al., 2016).

Azad Jammu and Kashmir (AJK) is a territory that connects Pakistan with China and India. Kashmir has a historical background and it was an independent empire in the $18^{\text {th }}$ century but later on during 1940s decade when India and Pakistan emerged on the map of world, this state was tetra-furcated into four sections; one of those is called as AJK (Ishtiaq et al., 2013b). Azad Jammu and Kashmir state has ten districts and Bhimber is one of these and it is located at the southern side connecting District Gujrat of Pakistan and Districts Rajori and Jammu of the Indian part of Kashmir. The study area of Watala National Park (WNP) and allied villages is located in Tehsil Barnala of District Bhimber, AJK. Collectively Districts Mirpur and Bhimber make one division of AJK and it consists of $2526 \mathrm{~km}^{2}$ area (Fig. 1). District Bhimber has plain area with some high mountains in Tehsil Samahni only and its area is $1516 \mathrm{~km}^{2}$. The population of District Bhimber is 0.343 million with a growth rate of $2.6 \%$ and house hold size of 6.7 (Ishtiaq et al., 2016).

The climate of the study area is warm and temperate with an average annual temperature of $23.5^{\circ} \mathrm{C}$. The average rainfall is $752 \mathrm{~mm}$ in a year. June is the warmest month of the year, temperature fluctuates with range $40-48.2^{\circ} \mathrm{C}$. January is the coldest month of the year, with an average temperature of $12.1^{\circ} \mathrm{C}$. November is the driest month, with $5 \mathrm{~mm}$ of rainfall. In July, the precipitation reaches its peak, with an average of $222 \mathrm{~mm}$ (Mehmood et al., 2012; Ishtiaq et al., 2016). Study area (Watala) is located in the North-East of Azad Jammu and Kashmir along $32^{\circ} 54\left(32.9023^{\circ}\right) \mathrm{N}$ and $74^{\circ} 17\left(74.2962^{\circ}\right) \mathrm{E}$ at an average elevation of 444 $\mathrm{m}$ above sea level (GPS Garmin Nuvi) (Nadeem et al., 2014; Ishtiaq et al., 2016). 


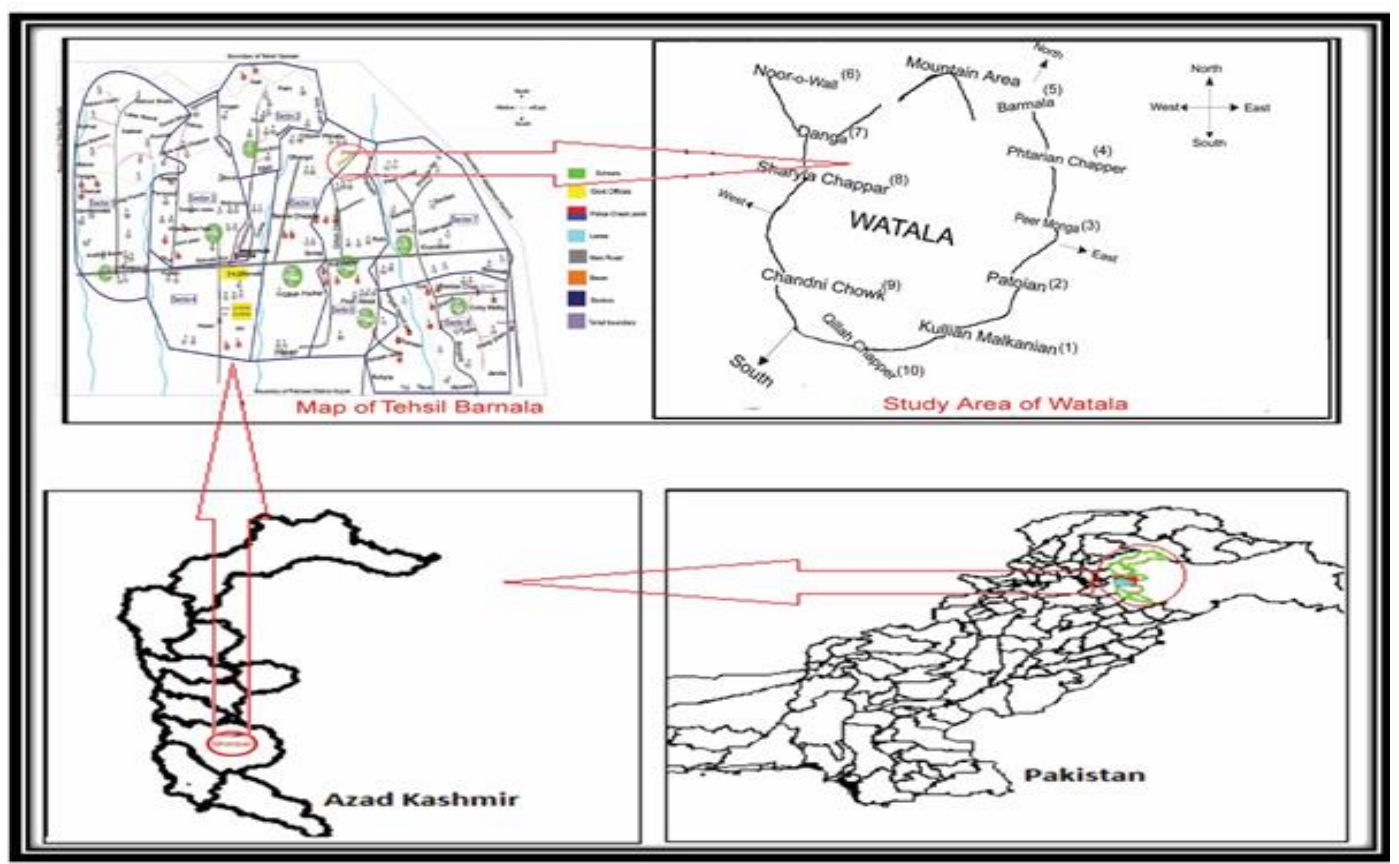

Figure 1. Map showing location of study area, Watala, District Bhimber within Tehsil Barnala, Azad Kashmir and Pakistan

WNP area has different ethnic groups residing such as Gojars, Jat, Rajpoot, Jaraal, Syed, Mirza, Kashmiri, Chibs and Awans (Ishtiaq et al., 2007a). In the area key languages spoken are Punjabi, Kashmiri, Saariki, Gojari, and Parhayee and each has different linguistic dialects that fluctuates from one village to other due to mixing of various cultures by bonds of marriages or by migration of people due to Indian firing, long drought spell, or any other cause (Ishtiaq et al., 2013b, 2016).

On many parts of Pakistan commendable work have been reported on EB studies by different workers describing that EB research is very important in drug discovery and development (Shinwari and Khan, 2000; Ishtiaq et al., 2007b). Albeit many sporadic research works are reported on EB studies of different areas of AJK (Qamar, 1996; Amjad et al., 2017; Dar et al., 2018; Ajaib et al., 2015; Ishtiaq et al., 2012, 2013b) but hitherto nothing is published on Watala National Park (WNP) and allied villages of District Bhimber, AJK. This is a first time an attempt to describe the ethnobotanical research on WNP using quantitative analysis by applying various microstatistical indices such as CF, RCF, FL, ICF and UVs. The IBCD, DMR and PR tools were used for determining biotic threat levels on the various plant species of WNP and then recommendations were made for the conservation of these taxa for their sustainable ecosystem services. The pivotal objectives of the research study were to: (i) study the plant biodiversity of the Watala National Park (WNP) and its allied area by preparing check list of plant flora; (ii) investigate and explore ethnobotanical potential of plants of the WNP in the life of rural communities by documenting multiple purpose uses; (iii) traditional folklore therapeutic recipes of medicinal plants (MPs) that may serve drug discovery research in the future; (iv) to document the cultural heritage of the indigenous communities of the WNP area and to calculate the conservation of various plants with recommendations for their protection and conservation for the future. 


\section{Materials and methods}

An ethnobotanical (EB) study was conducted during years 2015 and 2016 in Watala National Park (WNP) and allied villages of District Bhimber to collect the plant specimens for experimental analysis. During four seasons of the year, several planned and random field trips were conducted in the study area to collect EB information and data were recorded in triplicate manner for each parameter. The EB data were collected through use of Visual appraisal assessment (VAA) and rapid rural appraisal (RRA) methods (Okuthe et al., 2003; Ishtiaq et al., 2007b). In VAT, observations were made in wild areas and in the community houses and market visits and all of important information were instantly documented in a notebook. In RAA method, questionnaire method following Ishtiaq et al. (2013a, 2016) was used. In the process, structured and semi-structured interview patterns were used and data were collected from field visits and from local market surveys including botanic drug sellers (dealers), timber dealers, fuel wood sellers, local hakims and farmers in the research. The data collected from the local people included: botanical name, vernacular name, local name, folklore uses, therapeutic recipes, plants' part used, occurrence in area, characters involved in the collection, trade marketing, mode of usage and other related information like: disease name cured. According to economic values and drug potential, plants of WNP were further categorized into medicinal plants (MPs), food, fruits, fodder, vegetable, thatching, hedging, shelter, ornamental and fuel wood etc. based on the gathered data through interviewing questionnaire from botanic drug sellers, timber dealers, fuel wood sellers, local hakims and farmers. In this research analysis, preference was given to local elder people and hakims, who were the actual consumers and had a lot of indigenous traditional and cultural information about the plants and local ethnic groups with ritual paradigms (Ishtiaq et al., 2016). The collected data compiled in documentary form and it was compared with published and online papers for authenticity and verification.

\section{Data collection and identification of plants}

The plant specimens were collected from the area (WNP) for identification and extraction of EB data from villagers by showing them the plant specimens and asking them to answer the questions asked through different interview formats. The collected plants were dried, pressed, mounted properly on herbarium sheets and voucher numbers were assigned to each taxon according to protocol of Alexiades (1996), Cook (1995) and Ishtiaq et al. (2013b). All of these plant taxa were submitted for further reference in the Herbarium (MUH-), Department of Botany, Mirpur University of Science and Technology (MUST), Bhimber Campus. The plants were identified mainly with the help of Flora of Pakistan (www.eflora.com) following printed Flora book (Nasir and Ali, 1970-1989; Ali and Qaiser, 1993-2015), whereas the International Plant Name Index (IPNI) (www.ipni.org) was also used to obtain authentic botanical names.

\section{Quantitative ethnobotanical data analysis}

For the corroboration and to analyze the homogeneity of the collected ethnobotanical data, various quantitative indices were used. The collected EB data were formulated in form of a matrix (MS excel worksheet) and summarized as per protocol of Cook (1995) and Ishtiaq et al. (2013b). The obtained data were compared with previous research work published on the same area or on different areas of AJK but with same topic by 
using online searching for authentication and reliability. Due to stringent peer review procedure only authentic information were kept for the meta-analysis of the study. The applicability, reliability and authenticity of ethnobotanical research work was rechecked and supported by calculating frequency of citation (FC), use value (UV), relative frequency of citation (RFC), fidelity level (FL), informant consensus factor (ICF), data matrix ranking (DMR) and priority ranking (PR) microstatistical tools following protocols of Ishtiaq et al. (2007b) and Fisseha et al. (2009).

\section{Relative frequency of citation (RFC)}

The index of relative frequency of citation (RFC) was determined by using the following formula (Vijayakumar et al., 2015).

$$
\mathrm{RFC}=\mathrm{FC} / \mathrm{N}
$$

where $\mathrm{FC}$ is the number of informants reporting use of a particular species and $\mathrm{N}$ is the total number of informants.

Use value index $(U V)$

The use value was calculated by using the following formula (Vijayakumar et al., 2015).

$$
\mathrm{UV}=\sum \mathrm{Ui} / \mathrm{N}
$$

where $\mathrm{Ui}$ is the number of uses mentioned by each informant for a given species and $\mathrm{N}$ is the total number of informants.

\section{Fidelity level (FL)}

The fidelity level (FL), the percentage of informants claiming the use of a certain plant for the same major purpose was calculated for the most frequently reported usages or ailments as:

$$
\operatorname{FL}(\%)=\frac{\mathrm{Np}}{\mathrm{N}} \times 100
$$

where $\mathrm{Np}$ is the number of informants that claim a use of a plant species used for a particular purpose/disease and $\mathrm{N}$ is the number of informants that use the plants as a botanic/medicine to fill/treat any given demand/disease (Alexiades, 1996).

\section{Informant consensus factor (ICF)}

Informant consensus factor (ICF) was calculated for each category of aliments to identify the agreements of the informants on the reported medicures for the group of ICF was calculated as follows: number of use citations in each category (nur) minus the number of species used (nt), divided by the number of use citations in each category minus one (Heinrich et al., 1998). 


$$
\mathrm{ICF}=\frac{\text { nur }-\mathrm{nt}}{\text { nur }-1}
$$

\section{Data matrix ranking (DMR)}

Data matrix ranking (DMR) describes the multiple usages of one plant for various purposes by the indigenous community and the data is presented in tabular form with \% age index of each use-form aliments (Fisseha et al., 2009; Ishtiaq et al., 2013a).

\section{Priority ranking $(P R)$}

Priority ranking (PR) method was used for indicating the preference of the local people about the potential use of each plant in certain use and it describes the biotic pressure on the plants of the area and it assist to calculate the conservation status of various species in the study area (Ishtiaq et al., 2007a, 2013b).

\section{Results}

The Ethnobotanical research work is very important because it provides basic information on plant biodiversity, cultural diversity and traditional ethnomedicinal knowledge (TEK) of an area. The current research work was conducted in the rural area of Tehsil Barnala mainly focused on Watala National Park (WNP) and its allied village areas of Tehsil Barnala, District Bhimber Azad Jammu and Kashmir, Pakistan.

The area of WNP is very rich for biocultural diversity as it has a historic background. King of Dogra empire "Mahraja Hari Singh's" maternal grandparents belonged to this territory of WNP. The princess visited this region during his regime. There is a garden of mangoes in this region that is named as "Princess' Garden" locally called "Raani ka Baagh" which was established by the King in desire of the Princess (Baheem, 1890).

In this research work various parameters were studied which included the following steps: (i) social and geographical characteristics of the sample and study sites, shown in Table 1, (ii) Family-wise contribution and ethnomedicinal flora, (iii) plant collection, identification and preservation and (iv) documentation of floristic composition of the plants of the area.

Inhabitants of WNP and allied area (10 villages) were interviewed with the above said methodology for documentation of folklore therapeutics and ethnobotanical knowledge of the plants of the area (Fig. 1). The interviewees were of both gender with age range of 25-to-65 years and if age groups were made on the basis of 10 years age differences, then it was found that age group "56-65 years" was more knowledgeable due to their keen interest in local plants uses and their personal experience of life (Table 1). Less ethnobotanical knowledge was exhibited by age group "16-25 years" due to their preference for use of western medicines. However, the 56-65 years and 60<years age group showed high level of traditional knowledge which is a good sign of traditional knowledge consistency in the area. The graphical age difference of respondents is shown in (Fig. 2). 


$$
-12029 \text { - }
$$

Table 1. Social characteristics of study sites of Watala National Park, District Bhimber AJK, Pakistan

\begin{tabular}{c|c|c|c|c|c|c|c|c|c|c}
\hline $\begin{array}{c}\text { Village names } \\
\text { of WNP and } \\
\text { allied area }\end{array}$ & Barmala & $\begin{array}{c}\text { Saryala- } \\
\text { Chapper }\end{array}$ & Danga & $\begin{array}{c}\text { Pataria- } \\
\text { Chapper }\end{array}$ & $\begin{array}{c}\text { Noor-o- } \\
\text { Wall }\end{array}$ & $\begin{array}{c}\text { Chandni } \\
\text {-Choke }\end{array}$ & $\begin{array}{c}\text { Peer- } \\
\text { Monga }\end{array}$ & Patoian & $\begin{array}{c}\text { Kulian- } \\
\text { Malkanian }\end{array}$ & $\begin{array}{c}\text { Qilla- } \\
\text { Chapper }\end{array}$ \\
\hline $\begin{array}{c}\text { Village size } \\
\text { (number of } \\
\text { families) }\end{array}$ & 23 & 52 & 38 & 25 & 26 & 61 & 16 & 42 & 36 & 40 \\
\hline $\begin{array}{c}\text { Sample size } \\
\text { (number of } \\
\text { informants) }\end{array}$ & 9 & 6 & 10 & 7 & 9 & 11 & 5 & 7 & 9 & 6 \\
\hline $\begin{array}{c}\text { Dependency on } \\
\text { livestock as a } \\
\text { source of } \\
\text { income }\end{array}$ & $82 \%$ & $50 \%$ & $87 \%$ & $65 \%$ & $55 \%$ & $40 \%$ & $51 \%$ & $55 \%$ & $62 \%$ & $59 \%$ \\
\hline $\begin{array}{c}\text { Informants } \\
\text { average age }\end{array}$ & $56-21$ & $72-18$ & $69-16$ & $46-14$ & $50-12$ & $61-15$ & $67-20$ & $59-25$ & $67-28$ & $62-25$ \\
\hline $\begin{array}{c}\text { Average } \\
\text { number of } \\
\text { family } \\
\text { members }\end{array}$ & $14-5$ & $12-3$ & $18-3$ & $11-5$ & $10-2$ & $11-4$ & $16-2$ & $12-4$ & $10-2$ & $16-4$ \\
\hline Migration ratio & $10 \%$ & $2 \%$ & $1 \%$ & $0 \%$ & $1 \%$ & $0 \%$ & $0 \%$ & $0 \%$ & $0 \%$ & $0 \%$ \\
\hline Bilingualism & $9 \%$ & $40 \%$ & $35 \%$ & $20 \%$ & $30 \%$ & $45 \%$ & $25 \%$ & $35 \%$ & $42 \%$ & $30 \%$ \\
\hline $\begin{array}{c}\text { Elevation } \\
\text { (m.a.s.l.) }\end{array}$ & 396 & 410 & 465 & 438 & 398 & 472 & 458 & 442 & 394 & 447 \\
\hline
\end{tabular}

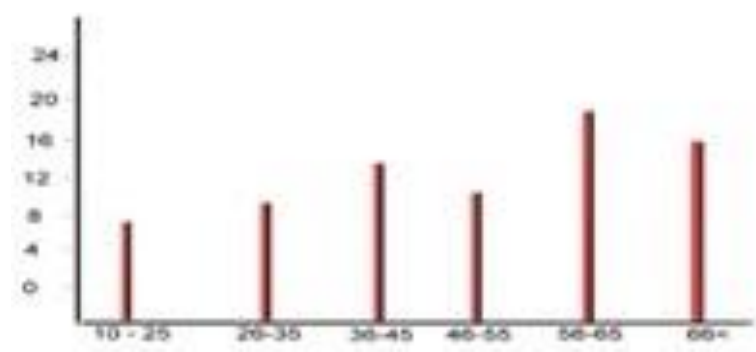

Figure 2. Graphical age difference of respondents of ethnobotanical study of Watala National Park of AJK, Pakistan

\section{Family-wise contribution and ethnobotanical flora of Watala National Park and allied areas}

For the documentation of ethnobotanical knowledge of the plants of Watala National Park (WNP) different plants were collected from the selected villages and WNP area according to protocol of Ishtiaq et al. (2007b). The collected plants were pressed, dried and mounted on herbarium sheets for preservation in the herbarium of the Department of Botany, Mirpur University of Science and Technology Bhimber AJK. Each collected plant specimen was assigned a herbarium voucher number with prefix: MUH-. The collected plants were herbaria numbers initiating from MUH-3031 to MUH-3122 (Table 3). The collected plants were verified and identified mainly with the help of Flora of Pakistan library booklets and online data (www.eflora.com) following Nasir and Ali (1970-1989) and Ali and Qaiser (1993-2015) whereas the International Plant Name Index (IPNI) (www.ipni.org) was also used to obtain correct botanical names, if not found in the herbarium or eflora website. Distribution of medicinal plant (MPs) species according to their family is presented in tabular form and it was 
found that Poaceae was the first having 15 species (16.31\%), followed by Amaranthaceae with 08 species $(8.69 \%)$ and Malvaceae ranked at third with 6 taxa $(6.52 \%)$ as described in Table 2 and in Figure 3 in graphical format.

Table 2. Percentage distribution of medicinal plants according to their family from Watala National Park of AJK

\begin{tabular}{c|c|c|c|c|c|c|c}
\hline $\begin{array}{c}\text { Sr. } \\
\text { no. }\end{array}$ & Family name & $\begin{array}{c}\text { No. of } \\
\text { spp. }\end{array}$ & $\begin{array}{c}\text { Percentage } \\
\text { contribution }\end{array}$ & $\begin{array}{c}\text { Sr. } \\
\text { no. }\end{array}$ & Family name & $\begin{array}{c}\text { No. of } \\
\text { spp. }\end{array}$ & $\begin{array}{c}\text { Percentage } \\
\text { contribution }\end{array}$ \\
\hline $1-$ & Acanthaceae & 3 & $3.26 \%$ & $20-$ & Flacourtiaceae & 2 & $2.17 \%$ \\
$2-$ & Amaranthaceae & 8 & $8.69 \%$ & $21-$ & Lamiaceae & 3 & $3.26 \%$ \\
$3-$ & Anacardiaceae & 1 & $1.08 \%$ & $22-$ & Malvaceae & 6 & $6.52 \%$ \\
$4-$ & Apocynaceae & 2 & $2.17 \%$ & $23-$ & Martyniaceae & 1 & $1.08 \%$ \\
$5-$ & Asclepiadaceae & 1 & $1.08 \%$ & $24-$ & Meliaceae & 1 & $1.08 \%$ \\
$6-$ & Asparagaceae & 1 & $1.08 \%$ & $25-$ & Mimosaceae & 4 & $4.35 \%$ \\
$7-$ & Asteraceae & 4 & $4.35 \%$ & $26-$ & Moraceae & 3 & $3.26 \%$ \\
$8-$ & Boraginaceae & 1 & $1.08 \%$ & $27-$ & Nyctaginaceae & 1 & $1.08 \%$ \\
9- & Brassicaceae & 1 & $1.08 \%$ & $28-$ & Oxalidaceae & 1 & $1.08 \%$ \\
$10-$ & Cactaceae & 1 & $1.08 \%$ & $29-$ & Papilionaceae & 4 & $4.35 \%$ \\
$11-$ & Cannabaceae & 1 & $1.08 \%$ & $30-$ & Poaceae & 15 & $16.31 \%$ \\
$12-$ & Capparidaceae & 3 & $3.26 \%$ & $31-$ & Potamogetanaceae & 1 & $1.08 \%$ \\
$13-$ & Celastraceae & 1 & $1.08 \%$ & $32-$ & Primulaceae & 1 & $1.08 \%$ \\
$14-$ & Combretaceae & 1 & $1.08 \%$ & $33-$ & Rhamnaceae & 2 & $2.17 \%$ \\
$15-$ & Commenlinaceae & 1 & $1.08 \%$ & $34-$ & Sapindaceae & 1 & $1.08 \%$ \\
$16-$ & Convalvulaceae & 4 & $4.35 \%$ & $35-$ & Solanaceae & 3 & $3.26 \%$ \\
$17-$ & Cucurbitaceae & 2 & $2.17 \%$ & $36-$ & Tiliaceae & 2 & $2.26 \%$ \\
$18-$ & Cyperaceae & 1 & $1.08 \%$ & $37-$ & Verbenaceae & 1 & $1.08 \%$ \\
$19-$ & Euphorbiaceae & 3 & $3.26 \%$ & & & & \\
\hline
\end{tabular}

\section{Documentation of wild plant species}

Ethnobotanical data of the wild plants of the WNP of AJK were documented containing voucher numbers, botanical names, vernacular name, family name, plant part used, field collection period, exact gathering sites, traditional medicinal uses and other use forms (Table 3). In the investigated area, 92 plant species belonging to 83 genera and 37 families were recorded. Among them, Poaceae ranked first having 15 species (16.31\%), Amaranthaceae was second having 8 species $(8.69 \%)$ whereas Malvaceae showed the third highest number having 6 species (6.52\%), respectively. Asteraceae, Convalvulaceae, Mimoaceae and Papilionaceae each having 4 species (4.35\%) while Acanthaceae, Capparidaceae, Euphorbiaceae, Lamiaceae, Moraceae and Solanaceae each has 3 species (3.26\%). Apocynaceae, Cucurbitaceae, Flacourtiaceae, Tiliaceae and Rhamnaceae each has 2 species (2.17\%). Anacardiaceae, Asparagaceae, Boraginaceae, Brassicaceae, Cactaceae, Cannabaceae, Celastraceae Cleomaceae, Combretaceae, Commenlinaceae, Cyperaceae, Martyniaceae, Meliaceae, Nyctaginaceae, Oxalidaceae, Potamogetanaceae, Primulaceae, Sapindaceae and Verbenaceae each has 1 species only (1.08\%). A pie-chart of medicinal plant species according to their contribution to each family is shown in (Fig. 3). Most of the plant species in the area identified as having an ethnomedicinal value were herbaceous (55\%), followed by trees $(20 \%)$, grasses $(12 \%)$, 
shrubs (10\%) and climbers (3\%) (Fig. 4). These results reflect the high altitude of the study area where the herbaceous flora is dominant with fewer grasses and trees.

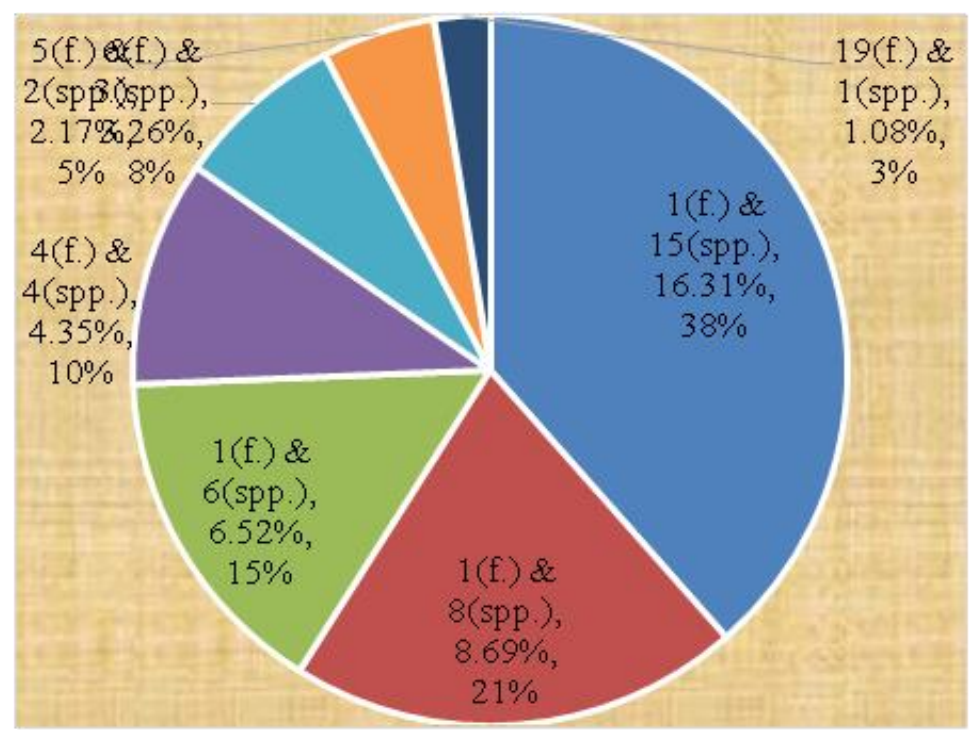

Figure 3. A pie-chart of medicinal plant species according to their contribution to their family (f: no. of families \& spp.: no. of species)

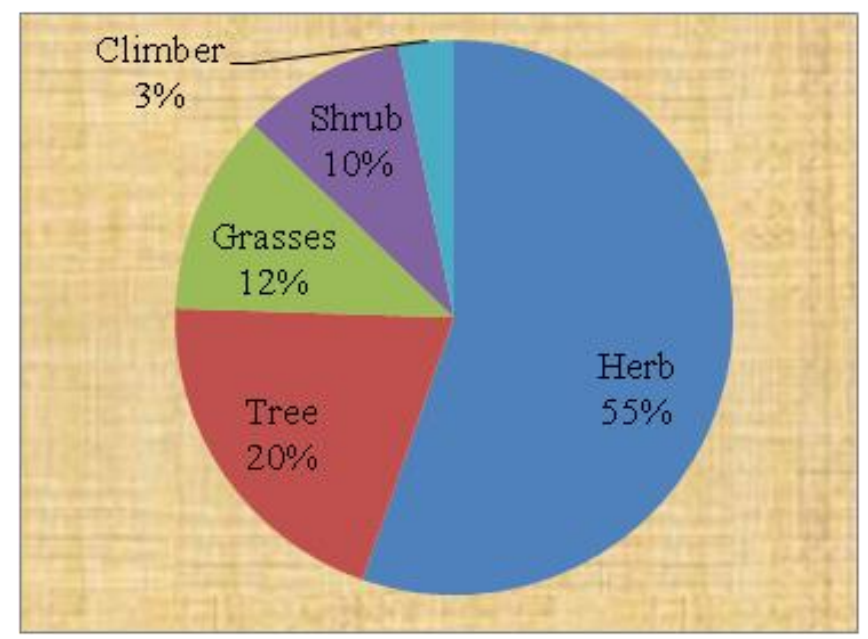

Figure 4. Life form of plants used in ethnobotanical study of Watala National Park of AJK, Pakistan

\section{Plant part(s) used}

Different plant parts are used in different ways in herbal medicines depending upon the knowledge of indigenous communities and accessibility of those plants to local inhabitants. In the present study, leaves $(\mathrm{L}=31 \%)$ were the most commonly used plant part in the herbal therapeutic preparations followed by whole plant (WP $=21 \%)$, root $(\mathrm{R}=10 \%)$, fruit \& seed $(\mathrm{FS}=8.8 \%)$, wood $(\mathrm{W}=7 \%)$, bark $(\mathrm{B}=6 \%)$, stem $(\mathrm{S}=5 \%)$, flowers $(\mathrm{F}=3 \%)$ and legume $(\mathrm{Lg}=1 \%)$ as shown in Figure 5. Ethnobotanical and medicinal uses of plants were also recorded and presented in Table 3. 


$$
-12032 \text { - }
$$

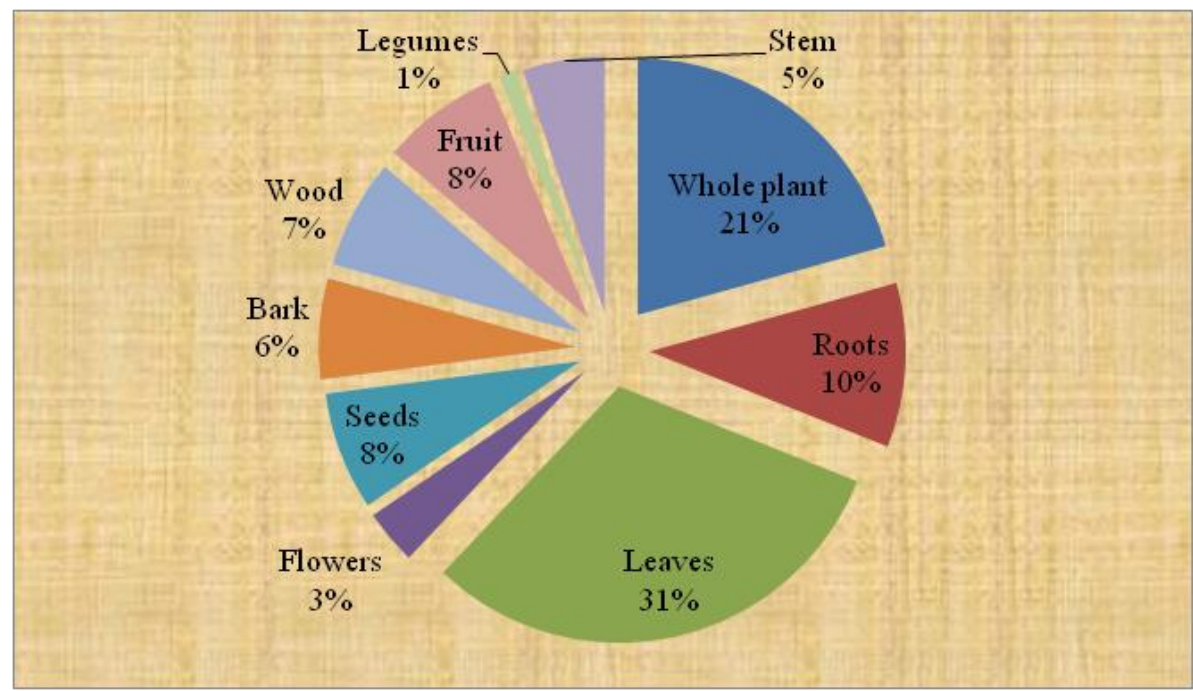

Figure 5. Plant parts used in herbal recipes in terms of\% age from Watala National Park of District Bhimber, AJK

\section{Method of preparation of folklore therapeutics and mode of administration}

Plants are very important source of food and medicines because plants contain many primary and secondary metabolites and the latter ones make them potential sources of medicinal use. Different parts of plants of various types and variable quantity of phytochemicals are used. The different plant parts were mostly used in herbal preparations in various modes such as decoction (22 spp.), extract (18 spp.), wet paste (17 spp.), dry \& powder (17 spp.), fuel (16 spp.), juice (11 spp.), palatable (9 spp.), vegetable (8 spp.), poultice (5 spp.) and gum (4 spp.). During the research various methods of folklore tonics' preparation were documented by interviewing the indigenous inhabitants of WNP and allied villages. Common form and mode of herbal therapeutics formation and its administration form were as: food/fodder (direct WP used) with the highest value (25\%), and decoction, paste, juice, powder, extract, tea and gum as the least used form (6\%) (Fig. 6).

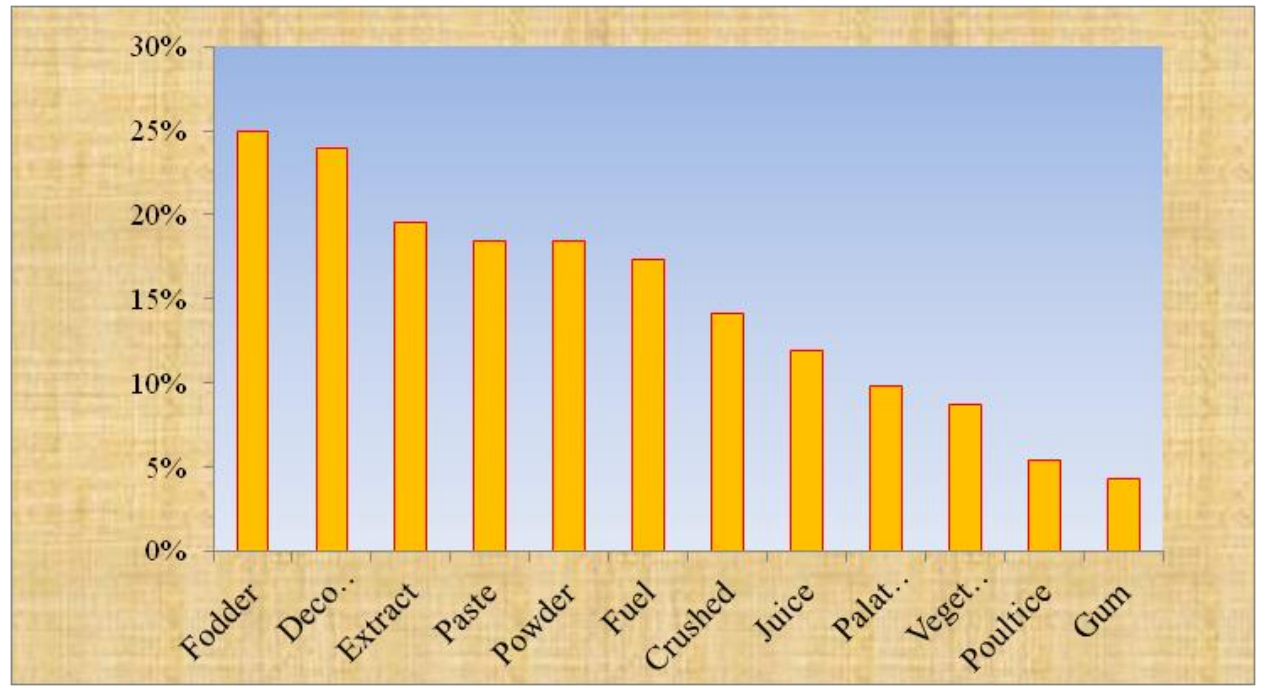

Figure 6. Common methods of preparation of folklore therapeutics and their mode of administration 
Table 3. Traditional ethnomedicinal and ethnobotanical uses of wild plants recorded from study area Watala National Park of District Bhimber of $A J K$

\begin{tabular}{|c|c|c|c|c|c|c|c|c|c|c|c|}
\hline Sr\# & \begin{tabular}{|c|} 
Family, botanical \\
name \& voucher no.
\end{tabular} & Habit & $\begin{array}{l}\text { Commo } \\
\text { n name }\end{array}$ & $\begin{array}{l}\text { Used } \\
\text { parts }\end{array}$ & $\begin{array}{c}\text { Gathering } \\
\text { period }\end{array}$ & $\begin{array}{c}\text { Gathering } \\
\text { area(s) }\end{array}$ & Traditional medicinal uses & $\begin{array}{c}\text { Ethnobotanical } \\
\text { uses }\end{array}$ & FC & RFC & $\mathbf{U V}$ \\
\hline \multicolumn{12}{|c|}{ (1) Acanthaceae } \\
\hline $1-$ & $\begin{array}{l}\text { Dicliptera } \\
\text { bupleuroides Nees } \\
\text { MUH-3031 }\end{array}$ & Herb & Kalu & $\begin{array}{l}\text { Whole } \\
\text { plant }\end{array}$ & Spring & Waste-land & $\begin{array}{c}\text { The poultice is used for scabies. The host insect } \\
\text { from this plant is collected to make powder, which } \\
\text { is very effective to cure pneumonia and } \\
\text { hypertension }\end{array}$ & $\begin{array}{l}\text { It is used as fuel in } \\
\text { dried form. }\end{array}$ & 48 & 0.61 & 0.63 \\
\hline $2-$ & $\begin{array}{l}\text { Justicia adhatoda L. } \\
\quad \text { MUH-3032 }\end{array}$ & Herb & Bhaker & $\begin{array}{c}\text { Leaves } \\
\text { and almost } \\
\text { whole } \\
\text { plant }\end{array}$ & Spring & Waste-land & $\begin{array}{c}\text { Half } \mathrm{kg} \text { of fresh leaves is extracted with } 500 \mathrm{ml} \\
\text { water, used against diabetes and in blood } \\
\text { purification. Leaves and flowers are taken, dried } \\
\text { under shade, crushed to acquire powder, } 50 \mathrm{gm} \text { of } \\
\text { this powder is mixed in } 15 \mathrm{ml} \text { of honey and used to } \\
\text { treatment of chest infection. Decoction of leaves is } \\
\text { used for skin infection. The stem and leaves are } \\
\text { useful for fever and hypertension }\end{array}$ & $\begin{array}{l}\text { It is used for } \\
\text { thatching, fuel } \\
\text {,hedging, shadow } \\
\text { for other micro- } \\
\text { plants, and used as } \\
\text { fodder }\end{array}$ & No & 0.66 & 0.68 \\
\hline $3-$ & $\begin{array}{c}\text { Peristrophe } \\
\text { paniculata (Forssk.) } \\
\text { Brummitt } \\
\text { MUH-3033 } \\
\end{array}$ & Herb & $\begin{array}{c}\text { Kaluu / } \\
\text { Kali-Buti }\end{array}$ & $\begin{array}{l}\text { Whole } \\
\text { plant }\end{array}$ & Spring & $\begin{array}{c}\text { Bushy- } \\
\text { vegetation }\end{array}$ & $\begin{array}{c}\text { The host insect from this plant is collected to make } \\
\text { powder, which is very effective to cure pneumonia } \\
\text { and hypertension }\end{array}$ & $\begin{array}{l}\text { It is used as } \\
\text { fodder, fuel. }\end{array}$ & 19 & 0.24 & 0.31 \\
\hline \multicolumn{12}{|c|}{ (2) Amaranthaceae } \\
\hline 4- & $\begin{array}{c}\text { Achyranthes aspera } \\
\text { L. } \\
\text { MUH-3034 }\end{array}$ & Herb & $\begin{array}{l}\text { Puth- } \\
\text { Kanda }\end{array}$ & $\begin{array}{l}\text { Whole } \\
\text { plant }\end{array}$ & Spring & $\begin{array}{c}\text { Bushy- } \\
\text { vegetation }\end{array}$ & $\begin{array}{l}\text { The paste acquired from the root has been used to } \\
\text { cure snake bite. Decoction is diuretic. Seeds and } \\
\text { leaves are given in prolepses in cattle. Seed powder } \\
\text { is also used in treatment of strong abdominal pain. } \\
\text { Shade dried whole plant powder is mixed with } \\
\text { honey is effective for pneumonia }\end{array}$ & $\begin{array}{l}\text { It is eaten as } \\
\text { fodder, also used } \\
\text { as fuel in dried } \\
\text { form. }\end{array}$ & 46 & 0.58 & 0.52 \\
\hline $5-$ & $\begin{array}{l}\text { Aerva sanguinolenta } \\
\text { (L.) Blume } \\
\text { MUH-3035 }\end{array}$ & Herb & Booti & Branches & Spring & $\begin{array}{c}\text { Bushy- } \\
\text { vegetation }\end{array}$ & $\begin{array}{l}\text { A decoction of immature branches is used to cure } \\
\text { haematuria and irregular or painful menstruation }\end{array}$ & $\begin{array}{l}\text { It is used as fodder } \\
\text { and bioremediator }\end{array}$ & 11 & 0.14 & 0.22 \\
\hline 6- & $\begin{array}{l}\text { Alternanthera } \\
\text { pungens Kunth } \\
\text { MUH-3036 }\end{array}$ & Herb & $\begin{array}{c}\text { Kanda- } \\
\text { Buti }\end{array}$ & $\begin{array}{c}\text { Leaves } \\
\text { and Roots }\end{array}$ & Spring & $\begin{array}{l}\text { Beside } \\
\text { pedestrian } \\
\text { passes }\end{array}$ & $\begin{array}{c}\text { Roots and leaves paste is beneficial for liver } \\
\text { disorder. Roots are used for eye tumor as well as its } \\
\text { decoction for cough and pulmonary disorder. } \\
\text { Leaves and roots are diuretic and used in blood } \\
\text { purification }\end{array}$ & $\begin{array}{l}\text { It is used for fuel } \\
\text { in dried form. }\end{array}$ & 18 & 0.23 & 0.16 \\
\hline
\end{tabular}




\begin{tabular}{|c|c|c|c|c|c|c|c|c|c|c|c|}
\hline $7-$ & $\begin{array}{l}\text { Amaranthus } \\
\text { graecizans L. } \\
\text { MUH-3037 }\end{array}$ & Herb & $\begin{array}{l}\text { Hardar- } \\
\text { Chalei }\end{array}$ & $\begin{array}{l}\text { Whole } \\
\text { plant }\end{array}$ & Spring & $\begin{array}{l}\text { Bushy- } \\
\text { vegetation }\end{array}$ & $\begin{array}{c}\text { The whole climber plant shade dried and ground to } \\
\text { form powder is used for cardiac diseases, diabetes } \\
\text { and aphrodisiac. Leaves are crushed with sugar and } \\
\text { occupied along with black tea for treating } \\
\text { constipation and gastrointestinal problems. Poultice } \\
\text { of leaf is prepared along with mustard oil for the } \\
\text { cure of abscesses }\end{array}$ & $\begin{array}{l}\text { It is used as } \\
\text { vegetable and } \\
\text { source of fodder. }\end{array}$ & 12 & 0.15 & 0.51 \\
\hline $8-$ & $\begin{array}{l}\text { Amaranthus viridis L. } \\
\quad \text { MUH-3038 }\end{array}$ & Herb & Ganar & $\begin{array}{l}\text { Whole } \\
\text { plant }\end{array}$ & Spring & $\begin{array}{l}\text { Bushy- } \\
\text { vegetation }\end{array}$ & $\begin{array}{c}\text { The leaves are used on snake bite and scorpion } \\
\text { sting. Root is used to restraint menstruation. It is } \\
\text { also used as vegetable (saag) }\end{array}$ & $\begin{array}{l}\text { It is used as } \\
\text { vegetable and } \\
\text { fodder }\end{array}$ & 43 & 0.54 & 0.24 \\
\hline 9- & $\begin{array}{l}\text { Celosia argentea L. } \\
\text { MUH-3039 }\end{array}$ & Herb & $\begin{array}{l}\text { Gutta- } \\
\text { Buti }\end{array}$ & $\begin{array}{l}\text { Whole } \\
\text { plant }\end{array}$ & Spring & Fertile-valley & $\begin{array}{c}\text { About } 20 \mathrm{ml} \text { of root extract is used to check undue } \\
\text { menstruation. It is used as fodder for cattle }\end{array}$ & $\begin{array}{c}\text { It is used as fodder } \\
\text { for cattle }\end{array}$ & 12 & 0.15 & 0.23 \\
\hline 10- & $\begin{array}{l}\text { Digera muricata }(\mathrm{L} .) \\
\text { Mart. } \\
\text { MUH-3040 }\end{array}$ & Herb & $\begin{array}{l}\text { Tandola / } \\
\text { Dawurra }\end{array}$ & $\begin{array}{l}\text { Whole } \\
\text { plant }\end{array}$ & Spring & Waste-land & $\begin{array}{l}\text { Extract of the whole plant juice is used as laxative. } \\
\text { Leaves are used as vegetable. The tender tips } \\
\text { extract is also used for kidney stones }\end{array}$ & $\begin{array}{c}\text { It is used as } \\
\text { bioremediator and } \\
\text { fodder and } \\
\text { vegetable }\end{array}$ & 29 & 0.36 & 0.15 \\
\hline $11-$ & $\begin{array}{l}\text { Pupalia lappacea }(\mathrm{L} .) \\
\text { Juss. } \\
\text { MUH-3041 }\end{array}$ & Herb & Jojera & $\begin{array}{l}\text { Whole } \\
\text { plant }\end{array}$ & Spring & $\begin{array}{l}\text { Bushy- } \\
\text { vegetation }\end{array}$ & $\begin{array}{c}\text { 10-12gm of fresh leaf paste mixed with } 50-60 \mathrm{ml} \text { of } \\
\text { Sesamum indicum oil, mixture is used for bone } \\
\text { fracture }\end{array}$ & $\begin{array}{c}\text { It is used as } \\
\text { vegetable and } \\
\text { chick feed }\end{array}$ & 57 & 0.72 & 0.54 \\
\hline \multicolumn{12}{|c|}{ (3) Anacardiaceae } \\
\hline $12-$ & $\begin{array}{l}\text { Lannea } \\
\text { coromandelica } \\
\text { (Houtt.) Merr. } \\
\text { MUH-3042 } \\
\end{array}$ & Tree & Gandela & $\begin{array}{l}\text { Whole } \\
\text { plant }\end{array}$ & Summer & Forest & $\begin{array}{c}\text { The gum acquired from the stem is used in } \\
\text { confectionery. The bark powder is used as a } \\
\text { flavoring. The plant is grown as a hedge as well as } \\
\text { a fence }\end{array}$ & $\begin{array}{c}\text { It is used as Fuel } \\
\text { wood, shelter and } \\
\text { fodder }\end{array}$ & 32 & 0.41 & 0.51 \\
\hline \multicolumn{12}{|c|}{ (4) Apocynaceae } \\
\hline $13-$ & $\begin{array}{l}\text { Carissa opaca Stapf } \\
\text { ex Haines. } \\
\text { MUH-3043 }\end{array}$ & Tree & Grunda & $\begin{array}{l}\text { Whole } \\
\text { plant }\end{array}$ & Spring & $\begin{array}{l}\text { Mountain- } \\
\text { forest }\end{array}$ & $\begin{array}{l}1 \mathrm{~kg} \text { decoction of fresh roots is used for asthma, } \\
\text { jaundice and kidney pain. } 30 \mathrm{~g} \text { dried root is crushed } \\
\text { to form powder and used in the cure of animal } \\
\text { wounds. Milky juice extracted from ripen fruit is } \\
\text { effectively used to cure iron deficiency, liver } \\
\text { disorders and blood deficiencies. Leaves are used } \\
\text { as fodder for goats and sheep. Stem and root are } \\
\text { used as fuel especially in local ovens } \\
\end{array}$ & $\begin{array}{l}\text { It is used as } \\
\text { fodder, fuel wood, } \\
\text { hedging and } \\
\text { fencing, fruit }\end{array}$ & 44 & 0.55 & 0.36 \\
\hline 14- & $\begin{array}{l}\text { Telosma cordata } \\
\text { (Burm. f.) Merr. } \\
\text { MUH-3044 }\end{array}$ & Herb & Pakalana & $\begin{array}{c}\text { Roots and } \\
\text { flowers }\end{array}$ & Spring & Waste-land & $\begin{array}{l}\text { The plump roots are used to make a sweetmeat. } \\
\text { The flowers are used in the treatment of } \\
\text { conjunctivitis }\end{array}$ & $\begin{array}{l}\text { It is used as fodder } \\
\text { and dry fuel }\end{array}$ & 51 & 0.65 & 0.72 \\
\hline
\end{tabular}

(5) Asclepiadaceae 


\begin{tabular}{|c|c|c|c|c|c|c|c|c|c|c|c|}
\hline $15-$ & $\begin{array}{l}\text { Calotropis procera } \\
\text { (Aiton) Dryand. } \\
\text { MUH-3045 }\end{array}$ & Shrub & Desi-aak & $\begin{array}{l}\text { Whole } \\
\text { plant }\end{array}$ & Summer & Barren-land & $\begin{array}{l}\text { Whole plant extract is used for dog bite. } \\
\text { Commonly latex is used for ring worm and skin } \\
\text { diseases. The milky juice is toxic }\end{array}$ & $\begin{array}{c}\text { Its toxic material, } \\
\text { kills goats if eaten } \\
\text { too much }\end{array}$ & 41 & 0.52 & 0.23 \\
\hline \multicolumn{12}{|c|}{ (6) Asparagaceae } \\
\hline $16-$ & $\begin{array}{l}\text { Asparagus gracilis } \\
\text { Browicz } \\
\text { MUH-3046 }\end{array}$ & Herb & - & $\begin{array}{l}\text { Whole } \\
\text { plant }\end{array}$ & Spring & $\begin{array}{l}\text { Bushy- } \\
\text { vegetation }\end{array}$ & $\begin{array}{l}\text { The plant is used for its anti-oxidant and anti- } \\
\text { urease activity }\end{array}$ & Fodder for animals & 23 & 0.29 & 0.41 \\
\hline \multicolumn{12}{|c|}{ (7) Asteraceae } \\
\hline $17-$ & $\begin{array}{l}\text { Artemisia scoparia } \\
\text { Waldst. \& Kitam. } \\
\text { MUH-3047 } \\
\end{array}$ & Herb & Chahuu & Leaves & Spring & Waste-land & Leaves are used as tonic and anthelmintic & $\begin{array}{l}\text { It is used as fodder } \\
\text { for goats, dry fuel }\end{array}$ & 41 & 0.52 & 0.72 \\
\hline $18-$ & $\begin{array}{c}\text { Bidens biternata } \\
\text { (Lour.) Merr. \& } \\
\text { Sherff } \\
\text { MUH-3048 }\end{array}$ & Herb & - & $\begin{array}{l}\text { Leaves } \\
\text { and seeds }\end{array}$ & Summer & Waste- land & $\begin{array}{l}\text { Leaf juice is used to treat eye and ear infections. } \\
\text { The scoured leaves are applied to skin infections as } \\
\text { haemostatic on wounds, and enfolded around the } \\
\text { umbilical cord of babies. The seeds are used as an } \\
\text { anthelmintic in animals }\end{array}$ & $\begin{array}{l}\text { It is used as fodder } \\
\text { and bioremediator }\end{array}$ & 12 & 0.15 & 0.55 \\
\hline 19- & $\begin{array}{c}\text { Tridax procumbens } \\
\text { (L.) L } \\
\text { MUH-3049 }\end{array}$ & Herb & $\begin{array}{l}\text { Coat } \\
\text { button }\end{array}$ & $\begin{array}{l}\text { Whole } \\
\text { plant }\end{array}$ & Spring & Waste-land & $\begin{array}{l}\text { The leaves are used in the treatment of bronchial } \\
\text { catarrh, dysentery and diarrhea. The leaves paste is } \\
\text { applied to reduce swelling of haemorrhoids and to } \\
\text { stop bleeding. Smoke produced by burning of the } \\
\text { plant is used to repel mosquitoes }\end{array}$ & $\begin{array}{l}\text { It is used as dry } \\
\text { fuel, and fodder. }\end{array}$ & 35 & 0.44 & 0.65 \\
\hline $20-$ & \begin{tabular}{|c|} 
Xanthium strumarium \\
L. \\
MUH-3050 \\
\end{tabular} & Herb & $\begin{array}{c}\text { Motta- } \\
\text { Jojera }\end{array}$ & $\begin{array}{l}\text { Whole } \\
\text { plant }\end{array}$ & Spring & $\begin{array}{l}\text { Bushy- } \\
\text { vegetation }\end{array}$ & $\begin{array}{l}120 \mathrm{ml} \text { decoction is prepared from } 60 \mathrm{mg} \text { of dried } \\
\text { root of this plant and used in diabetes. Leaves } \\
\text { decoction is used for long malarial fever }\end{array}$ & It is used as fuel & 59 & 0.75 & 0.52 \\
\hline \multicolumn{12}{|c|}{ (8) Boraginaceae } \\
\hline 21- & $\begin{array}{l}\text { Ehretia laevis Roxb. } \\
\text { MUH-3051 }\end{array}$ & Tree & $\begin{array}{c}\text { Cham- } \\
\text { road }\end{array}$ & $\begin{array}{c}\text { Stem and } \\
\text { bark }\end{array}$ & Summer & Forest & $\begin{array}{c}\text { Stem bark powder is used internally to check blood } \\
\text { dysentery for three days }\end{array}$ & $\begin{array}{c}\text { Fire wood, shelter, } \\
\text { fodder }\end{array}$ & 56 & 0.71 & 0.29 \\
\hline \multicolumn{12}{|c|}{ (9) Brassicaceae } \\
\hline $22-$ & $\begin{array}{l}\text { Coronopus didymus } \\
\text { (L.) Sm. } \\
\text { MUH-3052 }\end{array}$ & Herb & $\begin{array}{l}\text { Thandi- } \\
\text { Buti }\end{array}$ & $\begin{array}{l}\text { Whole } \\
\text { plant }\end{array}$ & Spring & Fertile-valley & $\begin{array}{l}\text { The plant is used as fumigant to repulse the insects. } \\
\text { The plant brings feelings of coolness in the body }\end{array}$ & $\begin{array}{l}\text { It is used as } \\
\text { bioindicator }\end{array}$ & 24 & 0.31 & 0.52 \\
\hline \multicolumn{12}{|c|}{ (10) Cactaceae } \\
\hline 23- & $\begin{array}{l}\text { Opuntia monacantha } \\
\text { (Wild.) Haw. } \\
\text { MUH-3053 } \\
\end{array}$ & Shrub & $\begin{array}{c}\text { Tarapar- } \\
\text { thor }\end{array}$ & $\begin{array}{l}\text { Whole } \\
\text { plant }\end{array}$ & Summer & Barren-land & It is used as hedge plant for fencing the fields & $\begin{array}{l}\text { It is used as } \\
\text { raticide }\end{array}$ & 23 & 0.29 & 0.15 \\
\hline
\end{tabular}

(11) Cannabaceae 


\begin{tabular}{|c|c|c|c|c|c|c|c|c|c|c|c|}
\hline $24-$ & $\begin{array}{c}\text { Cannabis sativa } \mathrm{L} . \\
\text { MUH-3054 }\end{array}$ & Herb & Bhaang & $\begin{array}{l}\text { Whole } \\
\text { plant }\end{array}$ & Summer & $\begin{array}{l}\text { Beside } \\
\text { pedestrain } \\
\text { passes }\end{array}$ & $\begin{array}{l}\text { The fruit and leaves are used as soporiferous } \\
\text { commonly called "Charas". Decoction of seeds is } \\
\text { given to cattle for increasing milk. Leaves are also } \\
\text { used for constipation, stomach diseases, } \\
\text { aphrodisiac and muscle contraction. It is also used } \\
\text { for stopping menses and whooping cough. Seeds } \\
\text { are used to stop releasing sperms }\end{array}$ & $\begin{array}{l}\text { It is used for fuel, } \\
\text { thatching material } \\
\text { used in mud- } \\
\text { houses }\end{array}$ & 31 & 0.39 & 0.44 \\
\hline \multicolumn{12}{|c|}{ (12) Capparidaceae } \\
\hline $25-$ & $\begin{array}{c}\text { Capparis sepiaria } \mathrm{L} . \\
\text { MUH-3055 }\end{array}$ & Shrub & Daddur & $\begin{array}{l}\text { Whole } \\
\text { plant }\end{array}$ & Spring & Forest & $\begin{array}{c}\text { The fruit is used to make powder and effectively } \\
\text { used to cure anemia, liver disorder and aphrodisiac. } \\
\text { The leaves are used as fodder for goats. Wood is } \\
\text { useful as fuel wood }\end{array}$ & $\begin{array}{l}\text { It is used as fuel } \\
\text { plant, fodder as } \\
\text { well }\end{array}$ & 23 & 0.29 & 0.71 \\
\hline $26-$ & $\begin{array}{c}\text { Cleome gynandra L. } \\
\text { MUH-3056 }\end{array}$ & Herb & $\begin{array}{l}\text { Talwar- } \\
\text { Buti }\end{array}$ & Leaves & Spring & Hedgerows & $\begin{array}{c}\text { Leaf juice is used as an ear-ache drop by drop. Half } \\
\text { tea-spoon of leaf juice is used daily for cold. } 10 \mathrm{~g} \text { of } \\
\text { leaves crushed with the same amount of pepper and } \\
\text { garlic extract is used daily for fertility to women } \\
\text { after completion of menstrual period }\end{array}$ & $\begin{array}{c}\text { It is used as fodder } \\
\text { plant }\end{array}$ & 15 & 0.18 & 0.31 \\
\hline $27-$ & $\begin{array}{l}\text { Crateva adansonii } \\
\text { DC. } \\
\text { MUH-3057 }\end{array}$ & Tree & Barna & $\begin{array}{l}\text { Whole } \\
\text { plant }\end{array}$ & Summer & Barren-land & $\begin{array}{l}\text { It is suitable in disorders of urinary organs, urinary } \\
\text { tract infections, pain and burning micturition, renal } \\
\text { and vesicle calculi. }\end{array}$ & $\begin{array}{c}\text { Fuel wood, shelter } \\
\text { and cattle shades }\end{array}$ & 25 & 0.32 & 0.29 \\
\hline \multicolumn{12}{|c|}{ (13) Celastraceae } \\
\hline $28-$ & $\begin{array}{l}\text { Maytenus royleana } \\
\text { (Wall. ex M.A. } \\
\text { Lawson.) Cufd. } \\
\text { MUH-3058 } \\
\end{array}$ & Shrub & Pataki & $\begin{array}{l}\text { Whole } \\
\text { plant }\end{array}$ & Summer & Forest & $\begin{array}{l}\text { Root extract is abortificent. Leaves are palatable. } \\
\text { Whole dry plant is used as fuel wood especially in } \\
\text { local ovens }\end{array}$ & $\begin{array}{l}\text { It is used as } \\
\text { fodder, hedging } \\
\text { plant }\end{array}$ & 31 & 0.39 & 0.39 \\
\hline \multicolumn{12}{|c|}{ (14) Combretaceae } \\
\hline $29-$ & $\begin{array}{l}\text { Anogeissus latifolia } \\
\text { (Roxb. ex DC.) } \\
\text { Wall.ex Bedd. } \\
\text { MUH-3059 } \\
\end{array}$ & Tree & Qaam & Stem bark & Summer & $\begin{array}{l}\text { Mountain- } \\
\text { forest }\end{array}$ & $\begin{array}{c}\text { Stem bark is crushed and soaked in water over } \\
\text { night, } 2 \text { spoons of the filtered extract is given twice } \\
\text { a day to cure whooping cough }\end{array}$ & $\begin{array}{l}\text { It is used as fuel } \\
\text { tree, shelter and } \\
\text { fodder }\end{array}$ & 19 & 0.24 & 0.18 \\
\hline \multicolumn{12}{|c|}{ (15) Commenlinaceae } \\
\hline $30-$ & $\begin{array}{l}\text { Commelina } \\
\text { benghalensis L. } \\
\text { MUH-3060 }\end{array}$ & Herb & Churra & $\begin{array}{l}\text { Whole } \\
\text { plant }\end{array}$ & Spring & Shady-land & $\begin{array}{l}\text { Leaves are used as vegetable (saag). Plant is used } \\
\text { as fodder for cattle. Leaves are laxative }\end{array}$ & $\begin{array}{c}\text { It is used as fodder } \\
\text { and vegetable }\end{array}$ & 15 & 0.18 & 0.29 \\
\hline
\end{tabular}




\begin{tabular}{|c|c|c|c|c|c|c|c|c|c|c|c|}
\hline $31-$ & $\begin{array}{l}\text { Cuscuta reflexa } \\
\text { Roxb. } \\
\text { MUH-3061 }\end{array}$ & Climber & $\begin{array}{l}\text { Neela- } \\
\text { Dhari }\end{array}$ & $\begin{array}{l}\text { Whole } \\
\text { plant }\end{array}$ & Summer & Fertile-valley & $\begin{array}{c}\text { Stem juice is useful for epilepsy and other mental } \\
\text { disorder. Paste of the plant powder is prepared in } \\
\text { butter and visibly useful for wounds. The whole } \\
\text { plant is crushed and boiled in 8liter of water for an } \\
\text { hour. It is filtered and advised the patient to take a } \\
\text { bath with this decoction without using soap for } \\
\text { scabies }\end{array}$ & $\begin{array}{c}\text { It is used for } \\
\text { roping and knitting } \\
\text { of wooden goods }\end{array}$ & 41 & 0.52 & 0.32 \\
\hline $32-$ & $\begin{array}{l}\text { Evolvulus alsinoides } \\
\text { (L.) L. } \\
\text { MUH-3062 } \\
\end{array}$ & Herb & $\begin{array}{c}\text { Vishnuki } \\
\text { ranthai }\end{array}$ & $\begin{array}{l}\text { Whole } \\
\text { plant }\end{array}$ & Spring & Fertile-land & $\begin{array}{l}\text { Whole plant extract is considered as strong anti- } \\
\text { dote for snake bite }\end{array}$ & It is used as fodder & 36 & 0.45 & 0.39 \\
\hline 33- & $\begin{array}{c}\text { Ipomoea carnea Jacq. } \\
\text { MUH-3063 }\end{array}$ & Shrub & $\begin{array}{l}\text { Valeiti- } \\
\text { Aak / } \\
\text { Jangli }\end{array}$ & $\begin{array}{l}\text { Whole } \\
\text { plant }\end{array}$ & Summer & Waste-land & $\begin{array}{l}\text { It is used as a medicinal and hedge plant. It is used } \\
\text { to stop the soil erosion in naked land. It is also used } \\
\text { as fuel wood }\end{array}$ & \begin{tabular}{|c|} 
It is used as fuel \\
plant, hedging one
\end{tabular} & 13 & 0.16 & 0.24 \\
\hline 34- & $\begin{array}{c}\text { Ipomoea pes-tigridis } \\
\text { L. } \\
\text { MUH-3064 }\end{array}$ & Climber & $\begin{array}{c}\text { Alra- } \\
\text { Kalyari / } \\
\text { Kangi- } \\
\text { poncha }\end{array}$ & $\begin{array}{l}\text { Whole } \\
\text { plant }\end{array}$ & Spring & $\begin{array}{l}\text { Bushy- } \\
\text { vegetation }\end{array}$ & $\begin{array}{c}\text { It is used for poultice sores, pimples, boils, } \\
\text { carbuncles etc. Entire creeper is crushed and the } \\
\text { juice is given orally for treatment of rabies, if one is } \\
\text { bitten by rabid dog. It is also used for wound } \\
\text { healing as well as various painful conditions like } \\
\text { head-ache, swelling, poisonous sting, snake bites } \\
\text { etc. }\end{array}$ & $\begin{array}{c}\text { It is used as fodder } \\
\text { and vegetable }\end{array}$ & 29 & 0.36 & 0.82 \\
\hline \multicolumn{12}{|c|}{ (17) Cucurbitaceae } \\
\hline $35-$ & $\begin{array}{c}\text { Coccinia grandis }(\mathrm{L} .) \\
\text { Voigt } \\
\text { MUH-3065 }\end{array}$ & Herb & $\begin{array}{c}\text { Chiwra/ } \\
\text { Kandyari }\end{array}$ & $\begin{array}{l}\text { Leaves, } \\
\text { root and } \\
\text { fruit }\end{array}$ & Spring & Waste-land & $\begin{array}{c}\text { Softened roots are used for diabetes. Softened } \\
\text { leaves are applied on swellings. Also its fruit, } \\
\text { leaves and stem mixed with neem is used to cure } \\
\text { diarrhea, blood purifier, loss of appetite and } \\
\text { indigestion }\end{array}$ & $\begin{array}{c}\text { It is used as fodder } \\
\text { and dry herb as } \\
\text { fuel. }\end{array}$ & 33 & 0.42 & 0.69 \\
\hline 36- & $\begin{array}{l}\text { Diplocyclos palmatus } \\
\text { (L.) C. MUH-3066 }\end{array}$ & Herb & $\begin{array}{c}\text { Cucumbe } \\
\text { r/ } \\
\text { Sivadond }\end{array}$ & Leaves & Summer & Waste-land & $\begin{array}{l}\text { Slightly warmed leaf juice is used as rheumatic } \\
\text { swellings in cattle }\end{array}$ & $\begin{array}{l}\text { It is used as fodder } \\
\text { and bioindicator }\end{array}$ & 49 & 0.62 & 0.45 \\
\hline \multicolumn{12}{|c|}{ (18) Cyperaceae } \\
\hline $37-$ & $\begin{array}{l}\text { Cyperus iria } \mathrm{L} . \\
\text { MUH-3067 }\end{array}$ & Herb & $\begin{array}{l}\text { Deela- } \\
\text { Kaa / } \\
\text { Muthri }\end{array}$ & $\begin{array}{l}\text { Tubers, } \\
\text { leaves }\end{array}$ & Spring & Fertile-land & $\begin{array}{c}\text { Decoction of crushed tubers is used for fevers. The } \\
\text { plant is considered good tonic, stimulant, } \\
\text { stomachic and astringent. It is used as fodder for } \\
\text { cattle }\end{array}$ & $\begin{array}{l}\text { It is used as fodder } \\
\text { and tonic herb }\end{array}$ & 42 & 0.53 & 0.16 \\
\hline \multicolumn{12}{|c|}{ (19) Euphorbiaceae } \\
\hline 38- & $\begin{array}{l}\text { Euphorbia hirta L. } \\
\text { MUH-3068 }\end{array}$ & Herb & Duudeil & $\begin{array}{l}\text { Whole } \\
\text { plant }\end{array}$ & Spring & $\begin{array}{l}\text { House- } \\
\text { garden }\end{array}$ & $\begin{array}{c}\text { Whole plant is very effective for liver disorder and } \\
\text { ring worms. Leaves juice is taken in diabetes. It is } \\
\text { effectively suitable for stomach pain }\end{array}$ & $\begin{array}{c}\text { It is used as fodder } \\
\text { herb }\end{array}$ & 21 & 0.26 & 0.36 \\
\hline
\end{tabular}




\begin{tabular}{|c|c|c|c|c|c|c|c|c|c|c|c|}
\hline 39- & $\begin{array}{c}\text { Euphorbia prostrata } \\
\text { Aiton } \\
\text { MUH-3069 }\end{array}$ & Herb & $\begin{array}{l}\text { Hazar- } \\
\text { Dani }\end{array}$ & $\begin{array}{l}\text { Whole } \\
\text { plant }\end{array}$ & Spring & $\begin{array}{l}\text { Beside } \\
\text { pedestrian } \\
\text { passes }\end{array}$ & $\begin{array}{l}\text { Dried plant is crushed to make powder and used as } \\
\text { anti-renal fall. Plant powder mixed with sugar is } \\
\text { effective for liver disorder. The paste is also } \\
\text { suitable in skin diseases. Plant decoction is used as } \\
\text { dermatocides, especially for ring worm. Dried plant } \\
\text { powder is used in diarrhea }\end{array}$ & $\begin{array}{l}\text { It is used as } \\
\text { protector }\end{array}$ & 54 & 0.68 & 0.82 \\
\hline 40- & $\begin{array}{c}\text { Ricinus communis L. } \\
\text { MUH-3070 }\end{array}$ & Shrub & Hernoli & $\begin{array}{l}\text { Leaves, } \\
\text { seeds and } \\
\quad \text { oil }\end{array}$ & Summer & Waste-land & \begin{tabular}{|c|} 
Leaves are emetics, poisonous and strongly \\
laxative. Poultice is applied to swelling. Castor oil \\
is laxative, oil is given in constipation before and \\
after child birth to mothers. Seeds are sedative \\
\end{tabular} & $\begin{array}{l}\text { It is use as fuel } \\
\text { wood and hedge } \\
\text { plants }\end{array}$ & 39 & 0.49 & 0.42 \\
\hline \multicolumn{12}{|c|}{ (20) Flacourtiaceae } \\
\hline $41-$ & $\begin{array}{c}\text { Casearia tomentosa } \\
\text { Roxb. MUH-3071 }\end{array}$ & Tree & $\begin{array}{c}\text { Cheela / } \\
\text { Jeela }\end{array}$ & $\begin{array}{l}\text { Leaves } \\
\text { and fruit }\end{array}$ & Summer & Waste-land & $\begin{array}{l}\text { The tender leaves are placed on abdomen of babies } \\
\text { to cure abdominal pain. The fruit is used for fish } \\
\text { poisoning. }\end{array}$ & $\begin{array}{l}\text { It is used as fuel } \\
\text { wood and fodder }\end{array}$ & 44 & 0.55 & 0.62 \\
\hline $42-$ & $\begin{array}{l}\text { Flacourtia indica } \\
\text { (Burm. f.) Merr. } \\
\text { MUH-3072 }\end{array}$ & Tree & Ko-ko & $\begin{array}{l}\text { Fruit and } \\
\text { wood }\end{array}$ & Summer & Forest & $\begin{array}{l}\text { Fruit is palatable and also suitable for liver disorder } \\
\text { and stomach disorder. Wood is used as fuel wood }\end{array}$ & \begin{tabular}{|c|} 
It is used as wild \\
fruit tree, fuel \\
wood
\end{tabular} & 47 & 0.59 & 0.53 \\
\hline \multicolumn{12}{|c|}{ (21) Lamiaceae } \\
\hline $43-$ & $\begin{array}{l}\text { Anisomeles indica } \\
\text { (L.) Kuntze. } \\
\text { MUH-3073 }\end{array}$ & Herb & $\begin{array}{c}\text { Boo-Buti } \\
\text { Sankhia }\end{array}$ & $\begin{array}{l}\text { Whole } \\
\text { plant }\end{array}$ & Spring & Fertile-valley & $\begin{array}{c}\text { Leaf paste is used to treat snake bite. Whole plant } \\
\text { extract is an excellent blood purifier. It is } \\
\text { effectively used against cancer, jaundice and } \\
\text { hepatitis }\end{array}$ & $\begin{array}{c}\text { It is used as fodder } \\
\text { plant }\end{array}$ & 42 & 0.53 & 0.26 \\
\hline 44- & $\begin{array}{l}\text { Leucas cephalotes } \\
\text { (Roth) Spreng. } \\
\text { MUH-3074 }\end{array}$ & Tree & Kareen & $\begin{array}{l}\text { Whole } \\
\text { plant }\end{array}$ & Summer & $\begin{array}{c}\text { Near human } \\
\text { settlement }\end{array}$ & $\begin{array}{c}\text { The seeds are used to control stomach-ache, as } \\
\text { contraception and abortifacient. The seed gum is } \\
\text { used as a binder. The plant is supposed to be a } \\
\text { worm repellent and also used in treating fevers, flu, } \\
\text { colds and reduce back pain and menstrual cramps. } \\
\text { The immature pods are palatable as well as } \\
\text { vegetable. The legumes act as a great source of } \\
\text { fodder for cattle }\end{array}$ & $\begin{array}{l}\text { It is used as fuel } \\
\text { wood and shadow } \\
\text { tree. Leaves as } \\
\text { fodder and } \\
\text { thatching }\end{array}$ & 49 & 0.62 & 0.68 \\
\hline $45-$ & $\begin{array}{c}\text { Ocimum americanum } \\
\text { L. } \\
\text { MUH-3075 }\end{array}$ & Herb & Naizboo & $\begin{array}{l}\text { Leaves } \\
\text { and seeds }\end{array}$ & Spring & $\begin{array}{l}\text { Near shady- } \\
\text { land }\end{array}$ & $\begin{array}{c}\text { The seeds are effectively used as aphrodisiac, gas } \\
\text { trouble, dyspepsia and indigestion. The leaves paste } \\
\text { is used for the treatment of skin diseases. It is also } \\
\text { applied to wounds and burns that are not healing } \\
\text { well }\end{array}$ & It is used as fodder & 50 & 0.63 & 0.55 \\
\hline
\end{tabular}




\begin{tabular}{|c|c|c|c|c|c|c|c|c|c|c|c|}
\hline $46-$ & $\begin{array}{c}\text { Abutilon bidentatum } \\
\text { Hochst. Ex A. Rich } \\
\text { MUH-3076 }\end{array}$ & Herb & $\begin{array}{c}\text { Kanghi } \\
\text { Buti }\end{array}$ & $\begin{array}{l}\text { Whole } \\
\text { plant }\end{array}$ & Spring & Waste-land & $\begin{array}{l}\text { The plant is used to comfort childbirth and expel } \\
\text { the placenta. The plant is used as bandage to } \\
\text { comfort kidney pain and is mixed with sticky rice } \\
\text { and it is useful to ulcers. The roots are also used to } \\
\text { cure cough and tooth-ache. The leaves are flowers } \\
\text { are suitable to abscesses }\end{array}$ & $\begin{array}{l}\text { It is used as } \\
\text { bioindicator and } \\
\text { fodder }\end{array}$ & 48 & 0.61 & 0.59 \\
\hline $47-$ & $\begin{array}{c}\text { Abutilon indicum (L.) } \\
\text { Sweet } \\
\text { MUH-3077 }\end{array}$ & Herb & $\begin{array}{c}\text { Kanghi } \\
\text { Buti }\end{array}$ & $\begin{array}{l}\text { Whole } \\
\text { plant }\end{array}$ & Spring & Waste-land & $\begin{array}{l}\text { Leaves decoction is beneficial to cure gout, } \\
\text { tuberculosis, ulcers and leucorrhea. The juice of } \\
\text { leaves supports to discharge toothache. The whole } \\
\text { plant can be stewed down into a decoction to } \\
\text { discharge the symptoms of lung ailments, } \\
\text { tuberculosis and bronchitis. It is also used in the } \\
\text { treatment of colds and fever }\end{array}$ & $\begin{array}{c}\text { It is used as fodder } \\
\text { plant }\end{array}$ & 34 & 0.43 & 0.53 \\
\hline $48-$ & $\begin{array}{c}\text { Malvastrum } \\
\text { coromandelianum } \\
\text { (L.) Garcke } \\
\text { MUH-3078 }\end{array}$ & Herb & $\begin{array}{c}\text { Hatmii- } \\
\text { Khubazii }\end{array}$ & $\begin{array}{l}\text { Leaves } \\
\text { and } \\
\text { flowers }\end{array}$ & Spring & Fertile-land & Leaves and flowers are used as aphrodisiac & $\begin{array}{l}\text { It is used as } \\
\text { bioremediator }\end{array}$ & 52 & 0.66 & 0.62 \\
\hline $49-$ & $\begin{array}{l}\text { Sida cordata (Burm. } \\
\text { f.) Borss. Waalk. } \\
\text { MUH-3079 }\end{array}$ & Herb & Paavani & Leaves & Spring & Shady-land & $\begin{array}{l}\text { Crushed leaves paste is applied externally for body } \\
\text { tumors, boils, cuts }\end{array}$ & $\begin{array}{c}\text { It is used as fodder } \\
\text { species }\end{array}$ & 38 & 0.48 & 0.43 \\
\hline $50-$ & $\begin{array}{l}\text { Sida cordifolia } \mathrm{L} . \\
\quad \text { MUH-3080 }\end{array}$ & Herb & Berela & $\begin{array}{l}\text { Leaves } \\
\text { and root }\end{array}$ & Spring & Shady-land & $\begin{array}{l}\text { Leaf extract is useful in dysentery as well as blood } \\
\text { fluctuation. Root extract is used in urinary troubles } \\
\text { and haematuria. The plant is used for tonic, in } \\
\text { fever, nervous disorders, colic, general debility and } \\
\text { heart irregularity }\end{array}$ & $\begin{array}{c}\text { It is used as fodder } \\
\text { plant }\end{array}$ & 59 & 0.75 & 0.29 \\
\hline $51-$ & $\begin{array}{c}\text { Urena lobata L. } \\
\text { MUH-3081 }\end{array}$ & Herb & $\begin{array}{l}\text { Kangi / } \\
\text { Burr- } \\
\text { Mallow }\end{array}$ & $\begin{array}{l}\text { Whole } \\
\text { plant }\end{array}$ & Spring & Shady-land & $\begin{array}{l}\text { The immature leaves are used as vegetable. The } \\
\text { leaves are used as poultice on wounds and skin } \\
\text { diseases. A decoction of root is used to treat colds, } \\
\text { dysentery, goiter, ingestion, malaria etc. The bark is } \\
\text { used to heal cuts. A decoction of flowers is used for } \\
\text { dry cough. A fiber is acquired from stem which is } \\
\text { used to make ropes, papers etc. }\end{array}$ & $\begin{array}{c}\text { It is used as fodder } \\
\text { and bioindicator } \\
\text { species }\end{array}$ & 54 & 0.68 & 0.23 \\
\hline \multicolumn{12}{|c|}{ (23) Martyniaceae } \\
\hline $52-$ & $\begin{array}{c}\text { Martynia annua L. } \\
\text { MUH-3082 }\end{array}$ & Herb & $\begin{array}{c}\text { Bichhu / } \\
\text { Kutta- } \\
\text { buti }\end{array}$ & $\begin{array}{l}\text { Leaves } \\
\text { and fruit }\end{array}$ & Spring & Bushy-land & Leaves and fruit are used in scorpion and snake bite & $\begin{array}{c}\text { It is used as fodder } \\
\text { plant }\end{array}$ & 18 & 0.23 & 0.66 \\
\hline
\end{tabular}




\begin{tabular}{|c|c|c|c|c|c|c|c|c|c|c|c|}
\hline 53- & $\begin{array}{c}\text { Azadirachta indica A. } \\
\text { Juss. } \\
\text { MUH-3083 }\end{array}$ & Tree & Neem & $\begin{array}{c}\text { Leaves, } \\
\text { seeds, bark } \\
\text {,wood and } \\
\text { stem }\end{array}$ & Summer & Barren-land & $\begin{array}{c}\text { Tender leaves of the plant are given daily to the } \\
\text { person suffering from diabetes. } 15 \mathrm{ml} \text { of leaves } \\
\text { extract is taken in hollow stomach continuously } \\
\text { one month for treatment of diabetes as well as } \\
\text { blood purification. Paste of } 6 \text { seeds with } 50 \mathrm{ml} \text { rice } \\
\text { and } 5 \mathrm{ml} \text { of ghee should be given after meal in case } \\
\text { of long standing diabetes. A shade dried powered } \\
\text { leaves are useful for blood purification and liver } \\
\text { diseases }\end{array}$ & $\begin{array}{l}\text { It is used as fuel } \\
\text { wood, kitchen } \\
\text { utnesils, mosquito } \\
\text { repellent and } \\
\text { shelter tree }\end{array}$ & 59 & 0.75 & 0.48 \\
\hline \multicolumn{12}{|c|}{ (25) Mimosaceae } \\
\hline 54- & $\begin{array}{c}\text { Albizia lebbeck (L.) } \\
\text { Benth. } \\
\text { MUH-3084 }\end{array}$ & Tree & $\begin{array}{l}\text { Sreeia / } \\
\text { shreen }\end{array}$ & $\begin{array}{c}\text { Leaves, } \\
\text { Wood and } \\
\text { Seeds }\end{array}$ & Summer & $\begin{array}{l}\text { Near human } \\
\text { settlement }\end{array}$ & $\begin{array}{l}\text { The flowers decoction is used for heart blockage. } \\
\text { Dried leaves and seeds are equal in weight mixed } \\
\text { with water then desiccated and honey is added. The } \\
\text { mixture is very effective for kidney disorder. Bark } \\
\text { decoction is used to treat diarrhea. Seeds are used } \\
\text { for treating severe kidney infection. Leaves provide } \\
\text { shade which is used as hallowed for the treatment } \\
\text { of various diseases. Wood is used as fuel wood and } \\
\text { for making agitator. Leaves are also delicious and } \\
\text { weight increasing in cattle }\end{array}$ & $\begin{array}{c}\text { It is used as fodder } \\
\text { and shelter tree. It } \\
\text { is used fuel wood } \\
\text { tree }\end{array}$ & 32 & 0.41 & 0.68 \\
\hline $55-$ & $\begin{array}{c}\text { Leucaena } \\
\text { leucocephala (Lam.) } \\
\text { de Wit. } \\
\text { MUH-3085 }\end{array}$ & Herb & $\begin{array}{l}\text { Trakhrad } \\
\text {-Medana }\end{array}$ & $\begin{array}{l}\text { Whole } \\
\text { plant }\end{array}$ & Spring & Fertile-land & $\begin{array}{l}\text { The leaves are used as vegetable. Whole plant is } \\
\text { used as fodder for cattle }\end{array}$ & $\begin{array}{l}\text { It is used as fodder } \\
\text { tree }\end{array}$ & 28 & 0.35 & 0.23 \\
\hline 56- & $\begin{array}{c}\text { Senegalia modesta } \\
\text { (Wall.) P. J. Hurter. } \\
\text { MUH-3086 }\end{array}$ & Tree & $\begin{array}{l}\text { Plai / } \\
\text { Pharli }\end{array}$ & $\begin{array}{c}\text { Gum,Leav } \\
\text { es and } \\
\text { Wood }\end{array}$ & Summer & $\begin{array}{l}\text { Mountain- } \\
\text { forest }\end{array}$ & $\begin{array}{l}\text { Gum and powder is prepared fresh leaves of this } \\
\text { plant, are mixed with wheat flour and desi ghee and } \\
\text { make Halwa that is used for back-ache. Gum } \\
\text { extracted from fruits is used as tonic and stimulant. } \\
\text { Leaves are used as fodder for goats. Wood is used } \\
\text { as fuel. Leaves powder mixed with milk and butter } \\
\text { is effectively treat kidney and urinary disorder }\end{array}$ & $\begin{array}{l}\text { It is used as } \\
\text { fodder, hedge } \\
\text { plant and gum tree, } \\
\text { it is used as fuel } \\
\text { wood }\end{array}$ & 52 & 0.66 & 0.75 \\
\hline
\end{tabular}




\begin{tabular}{|c|c|c|c|c|c|c|c|c|c|c|c|c|}
\hline $57-$ & $\begin{array}{c}\text { Vachellia nilotica }(\mathrm{L} .) \\
\text { P. J. Hurter \& Mabb. } \\
\text { MUH-3087 }\end{array}$ & Tree & Kikar & $\begin{array}{l}\text { Leaves, } \\
\text { Wood, } \\
\text { Flowers } \\
\text { and } \\
\text { Legumes }\end{array}$ & Summer & Barren-land & $\begin{array}{c}\text { Flowers are mixed with mustard oil, which is used } \\
\text { in the treatment of skin inflammation. Leaves } \\
\text { powder is used as toothpaste and gum is acquired } \\
\text { from stem is aphrodisiac. Extraction of fresh roots, } \\
\text { leaves and seeds are applied as alcohol (sharab) and } \\
\text { also narcotic. Four grams of gum is applied as paste } \\
\text { with water that is an effective aphrodisiac. Legume } \\
\text { is used as tonic, and for ailment of dysentery and } \\
\text { diabetes. Leaves and legumes are used as fodder } \\
\text { for goats. Wood is hard and is used for } \\
\text { construction, fuel and agricultural tools }\end{array}$ & $\begin{array}{r}\text { It } \\
\text { fodde } \\
\text { tree, } \\
\text { tree } \\
\text { he } \\
\text { tl }\end{array}$ & $\begin{array}{l}\text { used as } \\
\text { fuel wood } \\
\text { t is shelter } \\
\text { id used for } \\
\text { ging and } \\
\text { atching }\end{array}$ & 33 & 0.42 & 0.41 \\
\hline \multicolumn{13}{|c|}{ (26) Moraceae } \\
\hline $58-$ & $\begin{array}{c}\text { Ficus benghalensis L. } \\
\text { MUH-3088 }\end{array}$ & Tree & Bohar & $\begin{array}{l}\text { Whole } \\
\text { plant }\end{array}$ & Summer & Barren-land & $\begin{array}{c}\text { The latex acquired from aerial parts of the plants } \\
\text { (leaves and immature branches) and mixed with } \\
\text { honey is used orally to control high blood glucose } \\
\text { level as well as diabetics. Latex from aerial root is } \\
\text { energetic and used to fill cracking of feet. Latex is } \\
\text { aphrodisiac and effective in dysentery. Wood is } \\
\text { used as a fuel wood }\end{array}$ & \multicolumn{2}{|c|}{$\begin{array}{l}\text { It is used as fuel } \\
\text { wood, fodder and } \\
\text { thatching tree }\end{array}$} & 39 & 0.49 & 0.35 \\
\hline $59-$ & $\begin{array}{c}\text { Ficus palmata Forssk. } \\
\text { MUH-3089 }\end{array}$ & Tree & $\begin{array}{c}\text { Phugwar } \\
\text { a }\end{array}$ & $\begin{array}{l}\text { Whole } \\
\text { plant }\end{array}$ & Summer & Waste-land & $\begin{array}{c}\text { Fruit is palatable and laxative. It comforts the bee } \\
\text { sting by simple rubbing on the skin. Wood is hard } \\
\text { and used for making household tools. It is also used } \\
\text { as fuel wood }\end{array}$ & \multicolumn{2}{|c|}{$\begin{array}{l}\text { Fruit, fuel wood, } \\
\text { and fodder tree }\end{array}$} & 18 & 0.23 & 0.42 \\
\hline $60-$ & $\begin{array}{l}\text { Ficus religiosa } \mathrm{L} \text {. } \\
\text { MUH-3090 }\end{array}$ & Tree & Pipal & $\begin{array}{l}\text { Wood, } \\
\text { bark and } \\
\text { fruit }\end{array}$ & Summer & Waste-land & $\begin{array}{c}\text { Decoction of bark is used in vomiting, gonorrhea } \\
\text { and scabies. Burn the bark and make powder from } \\
\text { it and take } 5 \mathrm{~g} \text { of it orally with water for diarrhea. } \\
\text { Fruit is palatable and laxative. Wood is used as fuel } \\
\text { wood }\end{array}$ & \multicolumn{2}{|c|}{$\begin{array}{l}\text { It is used as fodder } \\
\text { and shelter and } \\
\text { fuel }\end{array}$} & 55 & 0.69 & 0.49 \\
\hline \multicolumn{13}{|c|}{ (27) Nyctaginaceae } \\
\hline $61-$ & \begin{tabular}{|c|} 
Boerhavia \\
procumbens Banks ex \\
Roxb. \\
MUH-3091 \\
\end{tabular} & Herb & Eeit- seit & $\begin{array}{c}\text { Roots and } \\
\text { leaves }\end{array}$ & Spring & $\begin{array}{l}\text { Near human } \\
\text { settlement }\end{array}$ & $\begin{array}{l}\text { Roots and leaves paste is useful for liver disorder. } \\
\text { Root decoction is useful for cough and pulmonary } \\
\text { disorder. Leaf paste is lapped on wasp sting as anti- } \\
\text { dote }\end{array}$ & Yes & Yes & 58 & 0.73 & 0.82 \\
\hline
\end{tabular}




\begin{tabular}{|c|c|c|c|c|c|c|c|c|c|c|c|}
\hline $62-$ & $\begin{array}{c}\text { Oxalis corniculata } \mathrm{L} . \\
\text { MUH-3092 }\end{array}$ & Herb & $\begin{array}{l}\text { Khati / } \\
\text { Luuni- } \\
\text { Buti }\end{array}$ & $\begin{array}{l}\text { Whole } \\
\text { plant }\end{array}$ & Spring & $\begin{array}{l}\text { Beside } \\
\text { pedestrian } \\
\text { passes }\end{array}$ & \begin{tabular}{|} 
Leaves powder is mixed with silver water, heated \\
and cooled and effectively used for blood \\
purification. Silver water mixed with honey is used \\
effectively for Alzheimer, fever and kidney \\
diseases. Leaves decoction is used in fever and \\
dysentery. Fresh leaves are used as vegetable. It is \\
also used as fodder and forage for cattle
\end{tabular} & It is used as fodder & 39 & 0.49 & 0.23 \\
\hline \multicolumn{12}{|c|}{ (29) Papilionaceae } \\
\hline 63- & $\begin{array}{c}\text { Butea monosperma } \\
\text { (Lam.) Taub } \\
\text { MUH-3093 }\end{array}$ & Tree & Cheechra & $\begin{array}{l}\text { Leaves, } \\
\text { flowers, } \\
\text { gum and } \\
\text { wood }\end{array}$ & Summer & Forest & $\begin{array}{c}10 \mathrm{ml} \text { of leaves extract is applied once a day for 5- } \\
10 \text { days on hollow stomach to reduces blood sugar } \\
\text { and also useful in glycosuria. Gum is mixed with } \\
\text { sugar and milk used as tonic and also given for } \\
\text { back-ache after birth in woman. Wood is used as } \\
\text { fuel wood }\end{array}$ & $\begin{array}{l}\text { It is used as fuel } \\
\text { and fodder tree, } \\
\text { thatching plant }\end{array}$ & 38 & 0.48 & 0.69 \\
\hline 64- & $\begin{array}{c}\text { Dalbergia sissoo DC. } \\
\text { MUH-3094 }\end{array}$ & Tree & $\begin{array}{l}\text { Sheesha } \\
\mathrm{m} / \text { Tali }\end{array}$ & $\begin{array}{l}\text { Whole } \\
\text { plant }\end{array}$ & Summer & $\begin{array}{l}\text { Mountain- } \\
\text { forest }\end{array}$ & $\begin{array}{c}70 \mathrm{~g} \text { of immature leaves of buds are crushed and } \\
\text { one glass of water is added to it and strained. The } \\
\text { strained decoction is used daily for treatment of } \\
\text { piles and jaundice. Wood boiled with water to } \\
\text { make syrup is used as blood purifier, irritation, } \\
\text { tumors and pimples. Ground leaves is bandaged on } \\
\text { mammary glands to reduce pain. Branches are used } \\
\text { as Muswak and kills worms in the teeth. Black } \\
\text { wood of old tree is used for making furniture as } \\
\text { well as fuel wood }\end{array}$ & $\begin{array}{l}\text { It is used timber } \\
\text { tree, fodder, } \\
\text { shelter making, } \\
\text { fuel wood, and } \\
\text { hedging and } \\
\text { fencing }\end{array}$ & 53 & 0.67 & 0.73 \\
\hline 65- & $\begin{array}{c}\text { Desmodium } \\
\text { gangetium (L.) DC } \\
\text { MUH-3095 }\end{array}$ & Herb & $\begin{array}{l}\text { Jojrii / } \\
\text { Salpani }\end{array}$ & $\begin{array}{l}\text { Whole } \\
\text { plant }\end{array}$ & Spring & Forest & $\begin{array}{l}\text { A decoction of leaves is used against gall bladder } \\
\text { and kidneys stones infections while a decoction of } \\
\text { root is used to treat kidney problems, swelling, } \\
\text { chronic fever, cough, diarrhea and dysentery. The } \\
\text { leaves are used for the treatment of head-ache } \\
\text { while the root is used for the treatment of tooth- } \\
\text { ache. The whole plant is used to be anthelmintic }\end{array}$ & $\begin{array}{c}\text { It is used as fodder } \\
\text { plant }\end{array}$ & 50 & 0.63 & 0.49 \\
\hline 66- & $\begin{array}{l}\text { Tephrosia purpurea } \\
\text { (L.) Pers. } \\
\text { MUH-3096 }\end{array}$ & Herb & Sarmak & $\begin{array}{l}\text { Whole } \\
\text { plant }\end{array}$ & Summer & Fertile-land & $\begin{array}{l}\text { The plant is used for curing many diseases like } \\
\text { leprosy, ulcers, asthma, tumors, liver, spleen, heart } \\
\text { and blood related diseases. The leaves and seeds is } \\
\text { used as fish poison. A decoction of the root is used } \\
\text { in treating depression, diarrhea, rheumatism and } \\
\text { urinary disorders. The root powder is used for } \\
\text { cleaning the teeth and reduces dental pains }\end{array}$ & $\begin{array}{l}\text { It is used for } \\
\text { fodder plant }\end{array}$ & 52 & 0.66 & 0.67 \\
\hline
\end{tabular}




\begin{tabular}{|c|c|c|c|c|c|c|c|c|c|c|c|}
\hline $67-$ & $\begin{array}{c}\text { Apluda mutica L. } \\
\text { MUH-3097 }\end{array}$ & Grasses & $\begin{array}{l}\text { Santali / } \\
\text { Chofki }\end{array}$ & $\begin{array}{l}\text { Whole } \\
\text { plant }\end{array}$ & Spring & Hedgerows & $\begin{array}{c}\text { Root is crushed and mixed with little } \\
\text { mustard oil, the paste is applied on the mouth } \\
\text { sore of cattle. It is used as a thatching } \\
\text { material by Santal clans }\end{array}$ & It is used as fodder & 24 & 0.31 & 0.63 \\
\hline 68- & $\begin{array}{l}\text { Chrysopogon fulvus } \\
\text { (Spreng.) Chiov } \\
\text { MUH-3098 } \\
\end{array}$ & Grasses & $\begin{array}{l}\text { Lamb-Kaa / } \\
\text { Khandol }\end{array}$ & $\begin{array}{l}\text { Whole } \\
\text { plant }\end{array}$ & Spring & Mountain & $\begin{array}{l}\text { Peels of Culm and bark is used for cough and } \\
\text { chest pain. It is also used as fodder for cattle }\end{array}$ & $\begin{array}{l}\text { It is used as } \\
\text { bioremediator }\end{array}$ & 46 & 0.58 & 0.66 \\
\hline 69- & $\begin{array}{l}\text { Cynodon dactylon } \\
\text { (L.) Pers. } \\
\text { MUH-3099 }\end{array}$ & Grasses & Khabal & $\begin{array}{l}\text { Whole } \\
\text { plant }\end{array}$ & Spring & $\begin{array}{l}\text { Beside } \\
\text { pedestrian } \\
\text { passes }\end{array}$ & $\begin{array}{l}\text { Paste of fresh leaves is applied to cut, wound } \\
\text { bleeding and piles. Juice of the plant is used } \\
\text { for diarrhea as well as diabetes. The whole } \\
\text { plant and flowers crushed and mixed with } \\
\text { milk and butter is useful on diabetic ulcers. } \\
\text { Plant extract mixed with salt is bandaged on } \\
\text { bone fracture. It is used as fodder for cattle }\end{array}$ & $\begin{array}{c}\text { It is used as fodder } \\
\text { and carpeting for } \\
\text { ground. It is used } \\
\text { as fuel if dried }\end{array}$ & 22 & 0.28 & 0.31 \\
\hline 70- & \begin{tabular}{|} 
Dactyloctenium \\
aegyptium (L.) Willd. \\
MUH-3100
\end{tabular} & Grasses & Palwan-kaa & $\begin{array}{l}\text { Whole } \\
\text { plant }\end{array}$ & Spring & Fertile-land & $\begin{array}{l}\text { Decoction of the whole plant is used for the } \\
\text { treatment of lumbago (back-ache). } \\
\text { Extraction of the leaves mixed with the seeds } \\
\text { is used to accelerate childbirth. A decoction } \\
\text { of the leaves is used as a cure for dysentery. } \\
\text { It is also used as fodder for cattle }\end{array}$ & $\begin{array}{c}\text { It is used fodder } \\
\text { and fuel source if } \\
\text { dried }\end{array}$ & 16 & 0.21 & 0.29 \\
\hline $71-$ & \begin{tabular}{|c|} 
Dichanthium \\
annulantum (Forssk.) \\
Stapf \\
MUH-3101 \\
\end{tabular} & Grasses & $\begin{array}{c}\text { Phuul-Kaa / } \\
\text { Marvel }\end{array}$ & $\begin{array}{l}\text { Whole } \\
\text { plant }\end{array}$ & Spring & $\begin{array}{l}\text { Beside } \\
\text { pedestrian } \\
\text { passes }\end{array}$ & $\begin{array}{l}\text { The whole plant is used as a favorite fodder } \\
\text { grass for animals, and also suitable for silage } \\
\text { and hay if cut earlier then flowering }\end{array}$ & $\begin{array}{l}\text { It is fodder and } \\
\text { bioindicator }\end{array}$ & 18 & 0.23 & 0.58 \\
\hline $72-$ & $\begin{array}{l}\text { Echinochloa colona } \\
\text { (L.) Link } \\
\text { MUH-3102 } \\
\end{array}$ & Grasses & $\begin{array}{l}\text { Sard-Kaa / } \\
\text { Jangli-rice }\end{array}$ & Leaves & Spring & Fertile-land & The whole plant is used as fodder for animals & $\begin{array}{c}\text { It is used as fodder } \\
\text { plant }\end{array}$ & 12 & 0.15 & 0.28 \\
\hline 73- & $\begin{array}{l}\text { Heteropogon } \\
\text { contortus }(\mathrm{L} .) \text { P. } \\
\text { Beauv. Ex Roem. \& } \\
\text { Schult. } \\
\text { MUH-3103 } \\
\end{array}$ & Grasses & Sryalla-Kaa & $\begin{array}{l}\text { Whole } \\
\text { plant }\end{array}$ & Spring & Barren-land & $\begin{array}{l}\text { The culms of the grass are used for thatching. } \\
\text { They are also used in mates. The root is } \\
\text { stimulative, diuretic and used in rheumatism. } \\
\text { It is also used as fodder for cattle }\end{array}$ & $\begin{array}{c}\text { It is used as fodder } \\
\text { and fuel plant in } \\
\text { dried form }\end{array}$ & 32 & 0.41 & 0.21 \\
\hline
\end{tabular}




\begin{tabular}{|c|c|c|c|c|c|c|c|c|c|c|c|}
\hline 74- & $\begin{array}{c}\text { Lolium temulentum } \mathrm{L} . \\
\mathrm{MUH}-3104\end{array}$ & Herb & Cheeri-Bajra & $\begin{array}{l}\text { Whole } \\
\text { plant }\end{array}$ & Spring & Waste-land & \begin{tabular}{|} 
The seeds are useful for fever by placing it in \\
sleep bed as well as decoction. Occasionally \\
used to treat head-ache, rheumatism and \\
sciatica. It is used to treat dizziness, \\
insomnia, blood congestion and stomach \\
problems. It may also be used for skin \\
problems like herpes, scurf and sores. The \\
plant is poisonous and can cause death
\end{tabular} & $\begin{array}{l}\text { It is used as fodder } \\
\text { and phyto- } \\
\text { remediator }\end{array}$ & 57 & 0.72 & 0.58 \\
\hline 75- & $\begin{array}{l}\text { Panicum antidotale } \\
\text { Retz. } \\
\text { MUH-3105 }\end{array}$ & Herb & Gyrum & $\begin{array}{l}\text { Whole } \\
\text { plant }\end{array}$ & Spring & Shady-land & $\begin{array}{l}\text { The whole plant is used as fodder for grazing } \\
\text { animals }\end{array}$ & $\begin{array}{c}\text { It is used as fodder } \\
\text { species }\end{array}$ & 19 & 0.24 & 0.23 \\
\hline 76- & \begin{tabular}{|c|} 
Paspalidium flavidum \\
(Retz.) A. Camus \\
MUH-3106 \\
\end{tabular} & Grasses & $\begin{array}{l}\text { Ghass / Arisi } \\
\text { pullu }\end{array}$ & $\begin{array}{l}\text { Grains and } \\
\text { seeds }\end{array}$ & Spring & Waste-land & $\begin{array}{l}\text { Grains are palatable. Seeds are boiled and } \\
\text { eaten as a substitute for rice by kattunaicka } \\
\text { and paniya clans }\end{array}$ & $\begin{array}{c}\text { It is used as fodder } \\
\text { plant }\end{array}$ & 32 & 0.41 & 0.15 \\
\hline 77- & $\begin{array}{l}\text { Saccharum } \\
\text { spontaneum L. } \\
\text { MUH-3107 }\end{array}$ & Herb & Saroot & $\begin{array}{l}\text { Whole } \\
\text { plant }\end{array}$ & Summer & Waste-land & $\begin{array}{l}\text { The honey acquired during July from this } \\
\text { plant is very effective for diabetes. Its pulped } \\
\text { stem is also effective for diabetic condition. }\end{array}$ & $\begin{array}{l}\text { It is used as } \\
\text { hedging and } \\
\text { thatching plant, } \\
\text { fodder }\end{array}$ & 41 & 0.52 & 0.41 \\
\hline 78- & $\begin{array}{l}\text { Saccharum } \\
\text { bengalense Retz. } \\
\text { MUH-3108 }\end{array}$ & Herb & Kaei & $\begin{array}{l}\text { Whole } \\
\text { plant }\end{array}$ & Summer & Waste-land & $\begin{array}{c}\text { Whole plant juice is mixed with milk for the } \\
\text { treatment of cough. Dry plant is used as } \\
\text { fodder for cattle. It is also used for making } \\
\text { ropes and for roof thatching }\end{array}$ & $\begin{array}{l}\text { It is used as fodder } \\
\text { and hedging plant }\end{array}$ & 35 & 0.44 & 0.72 \\
\hline 79- & $\begin{array}{l}\text { Sporobolus } \\
\text { coromandelianus } \\
\text { (Retz.) Kunth } \\
\text { MUH-3109 }\end{array}$ & Grasses & Cheeri-Kaa & $\begin{array}{l}\text { Whole } \\
\text { plant }\end{array}$ & Spring & Waste-land & $\begin{array}{l}\text { The plant is used to augment the blood, } \\
\text { reduce swellings and correct gonorrhea. A } \\
\text { fiber is acquired from the leaves }\end{array}$ & $\begin{array}{c}\text { It is used as fodder } \\
\text { species }\end{array}$ & 23 & 0.29 & 0.23 \\
\hline $80-$ & $\begin{array}{l}\text { Themeda anathera } \\
\text { (Nees ex Steud.) } \\
\text { Hack. MUH-3110 } \\
\end{array}$ & Grasses & Bhari-Kaaa & $\begin{array}{l}\text { Whole } \\
\text { plant }\end{array}$ & Spring & $\begin{array}{l}\text { Mountain- } \\
\text { forest }\end{array}$ & It is used as fodder for cattle & $\begin{array}{c}\text { It is used as fodder } \\
\text { and fuel species }\end{array}$ & 16 & 0.21 & 0.24 \\
\hline 81- & $\begin{array}{c}\text { Urochloa panicoides } \\
\text { P. Beauv. } \\
\text { MUH-3111 }\end{array}$ & Grasses & $\begin{array}{l}\text { Harat / Jhun- } \\
\quad \text { Kaa }\end{array}$ & $\begin{array}{l}\text { Whole } \\
\text { plant }\end{array}$ & Spring & Waste-land & $\begin{array}{l}\text { The whole plant is excellent fodder for cattle } \\
\text { and horses }\end{array}$ & $\begin{array}{c}\text { It is used as fodder } \\
\text { plant }\end{array}$ & 13 & 0.16 & 0.41 \\
\hline \multicolumn{12}{|c|}{ (31) Potamogetanaceaet } \\
\hline $82-$ & \begin{tabular}{|c|} 
Potamogeton nodosus \\
Poir. \\
MUH-3112 \\
\end{tabular} & Climber & Jujuli & $\begin{array}{l}\text { Whole } \\
\text { plant }\end{array}$ & Spring & Forest & $\begin{array}{l}\text { af extract is applied on irritating skin. Leaves } \\
\text { so used for constipation. Whole plant form is } \\
\text { excellent bio-fertilizer and used in crops }\end{array}$ & $\begin{array}{l}\text { It is fodder and } \\
\text { thatching plant }\end{array}$ & 35 & 0.44 & 0.52 \\
\hline
\end{tabular}

(32) Primulaceae 


\begin{tabular}{|c|c|c|c|c|c|c|c|c|c|c|c|}
\hline $83-$ & $\begin{array}{c}\text { Anagallis arvensis L. } \\
\text { MUH-3113 }\end{array}$ & Herb & $\begin{array}{l}\text { Neeli- } \\
\text { Buti }\end{array}$ & $\begin{array}{l}\text { Whole } \\
\text { plant }\end{array}$ & Summer & $\begin{array}{l}\text { Mountain- } \\
\text { forest }\end{array}$ & $\begin{array}{l}\text { Dried whole plant is crushed into powder. } 2 \mathrm{~g} \text { of the } \\
\text { powder with } 5 \mathrm{~g} \text { of wheat flour is mixed for cure of } \\
\text { rheumatism. It is also used as fodder for cattle }\end{array}$ & $\begin{array}{l}\text { It is used as fodder } \\
\text { plant }\end{array}$ & 43 & 0.54 & 0.44 \\
\hline \multicolumn{12}{|c|}{ (33) Rhamnaceae } \\
\hline $84-$ & $\begin{array}{c}\text { Ziziphus jujuba Mill. } \\
\text { MUH-3114 }\end{array}$ & Tree & Jannd & $\begin{array}{c}\text { Fruit as } \\
\text { well as } \\
\text { whole } \\
\text { plant }\end{array}$ & Summer & Forest & $\begin{array}{c}\text { Bake the fruit and eat for the treatment of stomach } \\
\text { problems. } 5 \mathrm{~g} \text { of root powder and } 7 \text { pieces of black } \\
\text { pepper, grind mixed and is used to cure diarrhea } \\
\text { and abdominal pain. Bark is mixed with honey to } \\
\text { use in diarrhea and dysentery. Fruit is palatable, } \\
\text { blood purifier and used in indigestion. The leaves } \\
\text { are used as fodder for goats. Wood is used as a fuel } \\
\text { wood }\end{array}$ & $\begin{array}{l}\text { It is used as fruit } \\
\text { tree, fodder and } \\
\text { fuel wood species, } \\
\text { hedging and } \\
\text { fencing }\end{array}$ & 59 & 0.75 & 0.29 \\
\hline $85-$ & $\begin{array}{l}\text { Ziziphus mauritiana } \\
\text { Lam. } \\
\text { MUH-3115 }\end{array}$ & Shrub & $\begin{array}{c}\text { Jangli- } \\
\text { Barii }\end{array}$ & $\begin{array}{l}\text { Whole } \\
\text { plant }\end{array}$ & Summer & $\begin{array}{l}\text { House- } \\
\text { garden }\end{array}$ & $\begin{array}{c}\text { Decoction of fruit and bark is mixed with a cup of } \\
\text { milk to treat constipation and dysentery. Fresh } \\
\text { leaves are chewed daily to lower blood glucose } \\
\text { level. Ripen fruits are palatable. Leaves are used as } \\
\text { fodder for goats }\end{array}$ & $\begin{array}{l}\text { It is used as fruit, } \\
\text { fuel wood, fodder } \\
\text { and hedge plant }\end{array}$ & 53 & 0.67 & 0.21 \\
\hline \multicolumn{12}{|c|}{ (34) Sapindaceae } \\
\hline $86-$ & $\begin{array}{l}\text { Dodonaea viscosa } \\
\text { (L.) Jacq } \\
\text { MUH-3116 }\end{array}$ & Shrub & Sanatha & $\begin{array}{l}\text { Whole } \\
\text { plant }\end{array}$ & Summer & Hilly-forest & $\begin{array}{c}\text { Shoots are collected to form besoms for sweeping } \\
\text { lawns. Bark is anthelmintic. Oil is extracted from } \\
\text { wood by keeping it on pain and used for tooth- } \\
\text { ache. Oil is used in cure of paralysis the patient. It } \\
\text { is also used as blood purifier. This plant is used for } \\
\text { fencing and wood is used as fuel wood. The leaves } \\
\text { are warmed and kept on joints to releive pains. } \\
\text { (rheumatism) }\end{array}$ & $\begin{array}{c}\text { It is used as } \\
\text { fodder, hedging } \\
\text { plant and shelter, } \\
\text { fuel wood in dried } \\
\text { form }\end{array}$ & 41 & 0.52 & 0.16 \\
\hline \multicolumn{12}{|c|}{ (35) Solanaceae } \\
\hline $87-$ & $\begin{array}{c}\text { Datura inoxia Mill. } \\
\text { MUH-3117 }\end{array}$ & Herb & Datura & $\begin{array}{c}\text { Fruit, } \\
\text { leaves and } \\
\text { seeds }\end{array}$ & Spring & $\begin{array}{c}\text { Bushy- } \\
\text { vegetation }\end{array}$ & $\begin{array}{c}\text { Leaves are used as repellant and vermicide. Fruit is } \\
\text { used to heat up the buffalos. Two and half fruit of } \\
\text { Datura is used to heat up the cattle. Seeds are } \\
\text { antipyretic and soporiferous }\end{array}$ & $\begin{array}{l}\text { It is used as } \\
\text { fodder, poisonous } \\
\text { plant and pesticide }\end{array}$ & 39 & 0.49 & 0.75 \\
\hline $88-$ & $\begin{array}{l}\text { Solanum nigrum L. } \\
\text { MUH-3118 }\end{array}$ & Herb & $\begin{array}{l}\text { Canch- } \\
\text { manch }\end{array}$ & $\begin{array}{l}\text { Shoots, } \\
\text { leaves and } \\
\text { fruit }\end{array}$ & Spring & Fertile-land & $\begin{array}{l}\text { Fresh aerial parts of the plant are used as vegetable } \\
\text { and to control diabetes. The leaves are crushed to } \\
\text { form a paste is used for inflammation, of body such } \\
\text { as legs and arms etc. It is also useful for liver } \\
\text { disorder. Whole plant juice is abortifacient and the } \\
\text { fetus is discharged in a short time. The leaf juice is } \\
\text { useful in kidney diseases. Leaf extract is also used } \\
\text { to heal up the wounds and tumors }\end{array}$ & $\begin{array}{l}\text { It is used as } \\
\text { vegetable, fruit } \\
\text { herb, fuel of dried } \\
\text { form }\end{array}$ & 26 & 0.33 & 0.67 \\
\hline
\end{tabular}

APPLIED ECOLOGY AND ENVIRONMENTAL RESEARCH 17(5):12023-12055.

http://www.aloki.hu • ISSN 15891623 (Print) • ISSN 17850037 (Online)

DOI: http://dx.doi.org/10.15666/aeer/1705_1202312055

( 2019 , ALÖKI Kft., Budapest, Hungary 


\begin{tabular}{|c|c|c|c|c|c|c|c|c|c|c|c|}
\hline 89- & $\begin{array}{l}\text { Solanum surattense } \\
\text { Burm. f. } \\
\text { MUH-3119 }\end{array}$ & Herb & $\begin{array}{l}\text { Jangli- } \\
\text { Betaun / } \\
\text { Mokri }\end{array}$ & $\begin{array}{l}\text { Whole } \\
\text { plant }\end{array}$ & Spring & Barren-land & $\begin{array}{l}\text { Fruit is dried, crushed and powder is used for the } \\
\text { treatment of abdomen pain, gas trouble, cough, } \\
\text { fever and pain in chest. It is expectorant, diuretic } \\
\text { and anti-gonorrhea }\end{array}$ & $\begin{array}{l}\text { It is used as } \\
\text { fodder, fruit, } \\
\text { vegetable herb }\end{array}$ & 31 & 0.39 & 0.52 \\
\hline \multicolumn{12}{|c|}{ (36) Tiliaceae } \\
\hline 90- & $\begin{array}{l}\text { Grewia optiva J.R. } \\
\text { Drumm. Ex Burret } \\
\quad \text { MUH-3120 }\end{array}$ & Tree & Dhaman & $\begin{array}{l}\text { Leaves, } \\
\text { fruit and } \\
\text { wood }\end{array}$ & Summer & Forest & $\begin{array}{l}\text { Fresh leaves are boiled in water to prepare } \\
\text { concentrated paste at low temperature. The } \\
\text { concentrated paste is used for joint pain. The outer } \\
\text { bark and fruit are soaked in water, the yield is a } \\
\text { gelatinous material which after drying, is used to } \\
\text { make tablets that are used as aphrodisiac. Leaves } \\
\text { are palatable for goats. Wood is used as fuel wood }\end{array}$ & $\begin{array}{c}\text { It is used as } \\
\text { fodder, fuel wood, } \\
\text { hedging and } \\
\text { thatching one }\end{array}$ & 23 & 0.29 & 0.49 \\
\hline 91- & $\begin{array}{l}\text { Triumfetta pentandra } \\
\text { A Rich. } \\
\text { MUH-3121 }\end{array}$ & Herb & $\begin{array}{c}\text { Permothi } \\
\mathrm{i}\end{array}$ & $\begin{array}{l}\text { Whole } \\
\text { plant }\end{array}$ & Spring & $\begin{array}{l}\text { Bushy- } \\
\text { vegetation }\end{array}$ & $\begin{array}{l}\text { The bark of green shoots of a mucilage used for } \\
\text { making sticky soups and sauces. The mucilage is } \\
\text { often used as baby food and for young children not } \\
\text { so far able to eat common starchy foods. Because } \\
\text { of its high energy value, the soup is given to } \\
\text { women who have delivered a child. It is also used } \\
\text { as appetizer. Fresh roots are used as a poultice on } \\
\text { sores and small wounds. The crushed leaf is } \\
\text { applied in plaster for treatment of goiter and } \\
\text { deformities }\end{array}$ & $\begin{array}{c}\text { It is used as fodder } \\
\text { species }\end{array}$ & 34 & 0.43 & 0.33 \\
\hline \multicolumn{12}{|c|}{ (37) Verbenaceae } \\
\hline 92- & $\begin{array}{l}\text { Vitex negundo L. } \\
\text { MUH-3122 }\end{array}$ & Shrub & Banna & $\begin{array}{l}\text { Leaves, } \\
\text { root, stem } \\
\text { and seeds }\end{array}$ & Summer & Barren-land & $\begin{array}{l}\text { The decoction of leaves is used for jaundice. } 60 \mathrm{~g} \\
\text { dried seeds, 30mg prior weed and 2-3 tea-spoon of } \\
\text { common salt are crushed to form powder that is } \\
\text { used for anti-pyretic, jaundice and gastrointestinal } \\
\text { problems. The seeds are crushed to acquire powder } \\
\text { and are taken with water for kidney stone. The } \\
\text { paste of leaf is used externally to treat snake bite. }\end{array}$ & $\begin{array}{l}\text { It is used as shelter } \\
\text { plant, fuel, } \\
\text { hedging and } \\
\text { fencing plant }\end{array}$ & 37 & 0.47 & 0.62 \\
\hline
\end{tabular}




\section{Relative frequency of citation and use values}

The RFC shows the local importance of every species with reference to the informants who cited uses of these plant species (Vitalini et al., 2012). In our work, RFC ranges from 0.75 to 0.14 (Table 3). Senegalia modesta, Grewia optiva, Pupalia lappacea, Xanthium strumarium, Ehretia laevis, Sida cordifolia, Azadirachta indica, Boerhavia procumbens, Ziziphus jujuba and Butea monosperma were the most cited ethnomedicinal plant species. These species are native to the area and have been known to local cultures over a long time period. Thus their specific properties for curing different diseases have become popularized and well-established among the indigenous people.

The use value (UV) is a measure of the types of uses attributed to a particular plant species. In the present study Datura inoxia, Dalbergia sissoo, Tephrosia purpurea, Abutilon bidentatum, Ricinus communis, Cuscuta reflexa, Calotropis procera and Digera muricata had UV values of $0.75,0.73,0.67,0.59,0.49,0.32,0.23$ and 0.15 , respectively. As the values for the UV and RFC are dynamic and change with location and with the knowledge of the people, so the values of UV and RFC may vary from area to area and even within the area.

\section{Determination of fidelity level (FL)}

The plants are used for treatment in different forms by local inhabitants of WNP of District Bhimber, AJK. This fidelity level analysis describes how the people of local area use a particular plant for the cure of specific disease and it also depicts their trust and belief on the specific plant used for cure that ailment. The analysis showed that highest FL values with first rank were Grewia optiva and Senegalia modesta $(100 \%$ each) while Justicia adhatoda was at number two with 93\% FL value and least Maytenus royleana with $23 \%$ weightage of worthiness in community popularity index (Table 4).

\section{Determination of informant consensus factor (ICF) for ethnobotanical study of Watala National Park of AJK}

The informant consensus factor (ICF) is a very important tool being used in ethnobotanical analysis and it describes how frequently a herb is used for cure to a particular disease. It indicates that how much community is unanimously agree to use different number of plant species for cure of particular disease or group of specific ailments. In this study, the highest values were obtained for jaundice, spleen and liver disorders (0.93); and kidney and urinary disorder (0.93). The ratio of cardio vascular diseases with reference of ICF was 0.50 (Table 5) and it is the least common disease prevailing in the area. These ICF calculations predictive of herbal therapeutics are used in the culture of indigenous communities.

\section{Direct matrix ranking (DMR)}

The data matrix ranking is an important microstatistical tool that describes what frequency of utilization is in an invariable form of a particular species for species purpose in daily life of man. This indirectly measures usage pressure on one species that is being exploited for different purposes by human beings. According to the informants' preview and key information Senegalia modesta has the highest DMR values and 
ranked at first while two taxa of genus Ficus named: Ficus palmata and Ficus religious were at number two. While plant Butea monosperma was third at $6^{\text {th }}$ rank as shown in Table 6. This DMR table depicts that there are several severe biotic threats due to anthropogenic interference on plants life.

Table 4. Fidelity level (FL) values of plants of Watala National Park and allied area, District Bhimber, AJK

\begin{tabular}{|c|c|c|c|c|}
\hline Species and family & $\begin{array}{c}\text { Vernacular } \\
\text { name }\end{array}$ & Family & Ethnomedicinal uses & $\begin{array}{l}\text { Fidelity } \\
\text { level (FL) }\end{array}$ \\
\hline Grewia optiva J. R. Drumm. Ex Burret & Dhaman & Tiliaceae & $\begin{array}{c}\text { Aphrodisiac, } \\
\text { antihypertension }\end{array}$ & $100 \%$ \\
\hline Senegalia modesta (Wall.) P. J. Hurter & Phulai & Mimosaceae & Tonic, anti-inflammatory & $100 \%$ \\
\hline Justicia adhatoda $\mathrm{L}$. & Baikar & Acanthaceae & Chest infection, hypertension & $93 \%$ \\
\hline Alternanthera pungens Kunth Bot.8 & Kand booti & Amaranthaceae & $\begin{array}{c}\text { Haematuria and menstrual } \\
\text { disorders }\end{array}$ & $82 \%$ \\
\hline Solanum nigrum $\mathrm{L}$. & Makoo & Solanaceae & Spleenic pain, liver disorders & $70 \%$ \\
\hline Ziziphus jujuba Mill. & Bairee & Rhamnaceae & Skin disorder, fruit source & $69 \%$ \\
\hline Butea monosperma (Lam.) Taub & Cheechra & Rhamnaceae & $\begin{array}{c}\text { Hypertension, } \\
\text { Hyperlipidemia, glycosuria }\end{array}$ & $66 \%$ \\
\hline Ficus palmata Forssk. & Phakwaree & Solanaceae & Leprosy, Rheumatism & $64 \%$ \\
\hline Flacourtia indica (Burm. f.) Merr. & Sheesham & Flacourtiaceae & Jaundice, Stomach disorders & $62 \%$ \\
\hline Albizia lebbeck (L.) Benth. & Shereen & Mimosaceae & Kidney, stomach & $61 \%$ \\
\hline Dalbergia sissoo DC. & Sheesham & Papilionaceae & $\begin{array}{c}\text { Sore throat, cough, } \\
\text { dysentery, stomachache }\end{array}$ & $60 \%$ \\
\hline Azadirachta indica A. Juss. & Dhareek & Miliaceae & $\begin{array}{l}\text { Syphilis, amenorrheae, } \\
\text { edema }\end{array}$ & $58 \%$ \\
\hline Calotropis procera (Aiton) Dryand. & Desi Aak & Asclepiadaceae & Skin disease, dog bite, sting & $57 \%$ \\
\hline Casearia tomentosa Roxb. & Cheela & Flacourtiaceae & Anti-ulcer, fish poisoning & $43 \%$ \\
\hline Cynodon dactylon (L.) Pers Poaceae & Khabal graas & Poaceae & $\begin{array}{c}\text { Antitumor hey fever, } \\
\text { flatulation, epilepsy, asthma }\end{array}$ & $40 \%$ \\
\hline Cuscuta reflexa Roxb. & Akaasch Bail & Convolvulaceae & $\begin{array}{l}\text { Elipsy, scabies, and wound } \\
\text { healer }\end{array}$ & $32 \%$ \\
\hline $\begin{array}{l}\text { Maytenus royleana (Wall. ex M. A. } \\
\text { Lawson.) Cufd. }\end{array}$ & Patakee & Celastraceae & Abortifacient agent & $23 \%$ \\
\hline
\end{tabular}

Table 5. Informant consensus factor (ICF) by categories of diseases in the study area (WNP) $A J K$

\begin{tabular}{c|c|c|c|c|c|c}
\hline S no & Category/plants used for disease(s) & Species & $\begin{array}{c}(\%) \text { All } \\
\text { species }\end{array}$ & $\begin{array}{c}\text { Use } \\
\text { citations }\end{array}$ & $\begin{array}{c}(\%) \text { All } \\
\text { citations }\end{array}$ & ICF \\
\hline 1 & Diabetics and blood pressure & 18 & $09.83 \%$ & 33 & $08.61 \%$ & 0.88 \\
2 & Fever, flu, headache, bronchitis, cough & 37 & $20.21 \%$ & 71 & $18.53 \%$ & 0.94 \\
3 & Epilepsy and mental disorders & 14 & $07.65 \%$ & 23 & $06.0 \%$ & 0.69 \\
4 & Stomachic, constipation, haemorrhoids & 26 & $14.20 \%$ & 48 & $12.51 \%$ & 0.88 \\
5 & Jaundice, spleen and liver disorders & 45 & $24.59 \%$ & 86 & $22.45 \%$ & 0.93 \\
6 & Cardiovascular disorders & 13 & $07.10 \%$ & 19 & $04.96 \%$ & 0.50 \\
7 & Rabies and other sting pains & 11 & $06.01 \%$ & 18 & $04.69 \%$ & 0.70 \\
8 & Gut, tuberculosis, ulcers and leucorrhea & 15 & $08.19 \%$ & 27 & $07.04 \%$ & 0.85 \\
9 & Arthritis and joint disorders & 16 & $08.74 \%$ & 30 & $07.83 \%$ & 0.93 \\
10 & Kidney and urinary disorder & 15 & $08.19 \%$ & 28 & $07.31 \%$ & 0.92 \\
\hline
\end{tabular}


Table 6. Direct matrix ranking (DMR) of plant species with different uses other than medicinal value (total score of 10 informants) in Watala National Park of District Bhimber $A J K$

\begin{tabular}{c|c|c|c|c|c|c|c}
\hline S. No & Uses & $\begin{array}{c}\text { Senegalia } \\
\text { modesta }\end{array}$ & $\begin{array}{c}\text { Ficus } \\
\text { palmata }\end{array}$ & $\begin{array}{c}\text { Butea } \\
\text { monosperma }\end{array}$ & $\begin{array}{c}\text { Ficus } \\
\text { religiosa }\end{array}$ & $\begin{array}{c}\text { Carica } \\
\text { opaca }\end{array}$ & $\begin{array}{c}\text { Ziziphus } \\
\text { jujba }\end{array}$ \\
\hline 1 & Construction & 56 & 26 & 11 & 25 & 11 & 15 \\
2 & Hedge, fencing & 22 & 05 & 14 & 21 & 52 & 29 \\
3 & Fuel wood & 40 & 19 & 16 & 37 & 37 & 30 \\
4 & Shelter, timber & 53 & 38 & 13 & 42 & 12 & 21 \\
5 & Fodder/feed & 04 & 10 & 33 & 25 & 15 & 16 \\
6 & Wild fruit/food & 09 & 04 & 01 & 19 & 30 & 33 \\
\hline \multicolumn{2}{r|}{ Total } & 184 & 102 & 88 & 169 & 157 & 144 \\
\hline
\end{tabular}

\section{Priority ranking $(P R)$}

The priority ranking (PR) analysis was also determined from the primary data collected from indigenous communities of WNP and allied villages of Barnala AJK. In order to explore the biotic pressure on plants of the study areas PR was calculated in tabular form and destructive threats were categorized in terms of six ranks: $6<5<4<3<2<1$; number 6 represents the most destructive value, as shown in Table 7. This determines how respondents of interviewees of the area declare that which parameter is the most dangerous for the flora or specific plant. The PR analysis depicts that fuel wood cutting of plants is a major threat for the flora of the area, followed by fire burnings (that may be accidental or deliberate fires). As village people mostly depend on wood or its products for making shelter or cattle sheds so this is third number key factor of plants degradation or loss from the environment. Among the studied eight threatening factors hedging and fencing cause the least impact on the loss of plant biodiversity of the area.

Table 7. Priority ranking $(P R)$ of factors perceived as threats to plant biodiversity based on their level of destructive effects in the study area (destructive threat order is: $6<5<4<3<2<1$; 6 is the most destructive value)

\begin{tabular}{|c|c|c|c|c|c|c|c|c|c|}
\hline \multirow{2}{*}{ Threat Factors } & \multicolumn{6}{|c|}{ Respondents (R1-R6) } & \multirow{2}{*}{ Total } & \multirow{2}{*}{ Percentage } & \multirow[t]{2}{*}{. $\mathbf{m}$} \\
\hline & $\mathbf{R 1}$ & $\mathbf{R 2}$ & $\mathbf{R 3}$ & $\mathbf{R 4}$ & $\mathbf{R 5}$ & R6 & & & \\
\hline Fuel source & 6 & 3 & 6 & 4 & 6 & 6 & 31 & 15.57 & $1^{\mathrm{st}}$ \\
\hline Construction of houses & 5 & 3 & 4 & 4 & 2 & 3 & 21 & 11.05 & $8^{\text {th }}$ \\
\hline Urbanization mechanism & 4 & 4 & 6 & 4 & 3 & 4 & 25 & 12.56 & $4^{\text {th }}$ \\
\hline Agriculture Clearing & 5 & 3 & 4 & 4 & 3 & 4 & 23 & 11.55 & $6^{\text {th }}$ \\
\hline Timber Cutting & 5 & 5 & 4 & 3 & 4 & 5 & 26 & 13.06 & $3^{\text {rd }}$ \\
\hline Fire Effects & 6 & 4 & 3 & 4 & 6 & 4 & 27 & 13.56 & $2^{\text {nd }}$ \\
\hline Fodder and feed & 1 & 4 & 5 & 3 & 6 & 5 & 24 & 12.06 & $5^{\text {th }}$ \\
\hline Hedging and Thatching & 2 & 4 & 5 & 6 & 5 & 2 & 22 & 11.07 & $7^{\text {th }}$ \\
\hline
\end{tabular}




\section{Discussion}

The plants are very important for the life of all human but their significance is increased many times for rural communities of any area because they depend solely on their natural habitat (plants) while coping their basic needs of life. In this research analysis, plants of the Watala National Park (WNP) and allied villages were surveyed and documented in the form of checklist. The key aim was to explore their traditional ethnomedicinal uses and describe their main ethnobotanical applications in daily life of that area. As indigenous communities of WNP and allied villages are the real owner of flora of that area, so their interviews were conducted using semi-structured and structured format in the form of questionnaires. WNP is an area which is declared as national park by the government and it is located in Tehsil Barnala of District Bhimber AJK, Pakistan. The area under study comprised of WNP area and allied ten villages and out of these "Chandni chowk" and "Danga" villages have high altitude 472 and 465 m.a.s.l., respectively. There is low literacy rate in these remote areas as compared to main stream city of Barnala and Bhimber District. The low education is due to remote areas and low income resources with less approach to good educational institutes (Mehmood et al., 2012). It is also compatible with work past ethnobotanists that modern generations and people living in urban areas have almost no knowledge about medicinal properties of plants (Alcorn, 1984; Altieri et al., 1987). This emphasis that the work conducted on EMs and EB of WNP and allied areas is of paramount significance to conserve the traditional ethnomedicinal knowledge on the plants of the area before it is diminished completely from this area.

In the EB investigation data on medicinal and folklore uses of plants of the Watala National Park (WNP) and allied villages was surveyed and 92 plant species were recorded in ethnomedicinal (EMs) and ethnobotanical (EB) perspectives. The analysis showed that people of age group "56-65 years" had the highest level of EB and EMs knowledge about the local flora of the area (Fig. 2). This is in coincidence with previous report of Ishtiaq et al. (2013a) that mostly old people have more EMs knowledge and traditional rituals are preferably followed by them. It was concluded that people of the study area primarily depend on the local vegetation to cope many of their daily needs. Generally inhabitants of the area cut trees/and other plants not only to make shelters and other household items but also sell them as timber and fuel wood for domestic and commercial purposes to earn livelihood and source of revenue; similar findings have been reported in past researchers that rural people of many other countries are also dependent on indigenous plant resources for their needs of life (Mcdichen and Mehl (1990).

Ethnobotany is an important and recent approach to study natural resource management by local people involvement. The EB study gives provision for the protection of traditional and cultural knowledge and rights of native people as intellectual property rights. This research on EB analysis of any area cascades significance on how plants and indigenous people of an area are mutually interconnected and dependent on each other in terms of ecosystem sustainability format. In the past some sporadic work has been conducted on other parts of AJK (Ajaib et al., 2014a) and very little is known on District Bhimber flora, particularly no research project is conducted on EB analysis of WNP and allied villages.

Very little work has been undertaken by legal professionals, environmentalists, NGOs or even human rights groups to secure Intellectual Property Rights for native people, as expressed by Martin (1995) and here WNP and allied villages are very 
neonate and nothing is found in printed or online literature. The present study area WNP and allied villages is an ecologically important area of District Bhimber, AJK but no attention previously had been given for the documentation and conservation of indigenous knowledge of the area.

Most of the native plants now exist only in graveyards and local people had a lot more information about these plants than the introduced plants. Similar results were also recorded by Meza and Vilagram (1991) in Chile on the level of knowledge of native flora, which was always greater for native flora than introduced species. The local inhabitants, having a little knowledge about the species and proper time of collections, from the poorest link in the trade of medicinal plants as reported by Ajaib et al. (2016) during ethnobotanical studies of wild plants of Tehsil Jatlan Azad Jammu and Kashmir. In WNP and allied areas the highest number of plants recorded for EMs and EB studies belonged to families Poaceae, Amaranthaceae and Malvaceae (Table 2) and the cause of this might be that taxa of these families have short life spell and can be grown out soon after monsoon rainfall and secondly the tree line is becoming scarce due to cutting and fire burnings (Ishtiaq et al., 2013a). Other taxa of families were also present in the form of herbs (55\%), shrubs (10\%), climbers and trees (20\%) with variable population occurrence in different villages but their community structures have not well established (Figs. 3 and 4), which might be underneath cause of sandy stone soil with few rainfall and deep water table in the area (Ishtiaq et al., 2016).

The present study revealed that the local people used some plant species for more than one purpose as tribal totally depended on the vegetation of the area for a variety of their needs. Some of the important multiple-usage plants included Senegalia modesta (Wall.) P. J. Hurter, Albizia lebbeck (L.) Benth, Carissa opaca Stapf ex Haines, Capparis sepiaria L, Dalbergia sissoo DC, Dodonaea viscosa (L.) Jacq, Flacourtia indica (Burm. f.) Merr, Ficus palmata Forssk, Ficus religiosa L, Heteropogon contortus (L.) P. Beauv. Ex Roem. \& Schult, Maytenus royleana (Wall. ex M. A. Lawson.) Cufd., Oxalis corniculata L, Grewia optiva J. R. Drumm. Ex Burret, Saccharum spontaneum L, Urena lobata L, Vachellia nilotica (L.) P. J. Hurter \& Mabb, Ziziphus jujuba Mill. Multiple-usage species provided fruits, vegetables, fuel wood, medicines and other requirements to the local population. This is being described in Table 4 that many plants are being utilized in admixture to cure one or more disease (s) and fidelity level (FL) also proves it (Ishtiaq et al., 2007b). The plant Senegalia modesta (Wall.) P. J. Hurter, has the highest FL (100\%), followed by Justicia adhatoda L. with 93\% FL value. Flacourtia indica (Burm. f.) Merr. had an FL value of $62 \%$. It is also believed by indigenous rural communities of the area that plants originated drugs "green drugs" are pure and with least or without toxic effects and this coincides with the doctrine of previous researchers (Ishtiaq et al., 2006b, 2007a). The VAA procedure described that ICF analysis of the data culminated that as people of the area living in rural areas and with hard working life style, so they suffer from the least cardiovascular disorders (ICF: 0.50) while common problems in the area were only minor seasonal diseases like fever, flu, headache, bronchitis, cough having the highest ICF (100\%), followed by jaundice, spleen and liver disorders (0.93 5) as shown in Table 5. Open life pattern and mosquito and high temperature with heat stroke waves may be the cause of this. Other cause of the liver and spleen disorders may be the use of open spring waters or ponds without proper hygienic measures (Erasto et al., 2005; Ishtiaq et al., 2006a, 2007a, 2010b).

One could assess the pressure on the flora of the area by the process of direct matric ranking (DMR) and the results depicted that many plants have been used in multifarious 
forms to cope the needs of life. In this study it was found that Senegalia modesta and Ficus palmata were being used for different purposes of life by indigenous people and hence in DMR analysis these were at first two positons, respectively (Table 6). This describes how the biotic pressure is present on flora of the area and same type of investigations had been recorded that multiple-propose uses creates conservation threats for trees and other plants (Medicken and Mehl, 1990). This all give potential picture of anthropogenic pressure on the local plants of the area and it thrills towards the loss of plants gradually and may be categorized as threatened, endangered or rare taxa, as it was also demonstrated by Ishtiaq et al. $(2006 \mathrm{~b}, 2007 \mathrm{~b})$ in their previous articles on other areas of AJK.

The research work on WNP and allied areas depicted that as local communities are dwelling in rural area, mostly illiterate with low income resources, so they have to solely depend on wild resources (plants and animals) utilization for livelihood. The priority ranking (PR) statistics is being used as to measure the highly threatening factors for the indigenous plants. The local people use plants for fuel wood, construction, food, fodder, shelter making for livestock, agricultural land preparation by clearing the wild flora of the area. It was found that using plants as fuel is the first threat followed by the fire burning at second (Table 7). The hedging and fencing is the least pressure generating factor being at number $7^{\text {th }}$ in analyzed factors. All these factors are keystone threats for the local plants of the area and similar information on threats for plant biodiversity of different areas of AJK and other countries as well (Ahmed and Siraj; 1996; Ishtiaq et al., 2007b). In the analysis it was found that the most threatened species was Butea monosperma with highest threatening frequency $(29.5 \%)$ being used in many needs by local people. Other commonly under threat plants are Dalbergia sissoo (19.5\%), Senegalia modesta (11.25\%), Grewia optiva (10.25\%), Ziziphus jujuba $(9.25 \%)$ as data shown in Table 8 . These MPs and other taxa are being ruthlessly and unsustainably used by the local communities of the WNP and allied areas for domestic and commercial means that is the main cause of debilitation of plant biodiversity occurrence in the area, ultimately leading towards threatening zone (Mehmood et al., 2012; Ahmed and Siraj, 1996). This all proves that the current scenario should not be ignored and planned biodiversity conservation activities may be introduced and implemented in collaboration with NGOs and Department of Forest with direct participation of the indigenous communities. Main plinth of the problem is unawareness cutting, timber mafia and ignition of fires and it should be tackled by application of incessant methodologies in cooperation with public and private joint venture programs.

Table 8. Frequency (\%) of threatened species in Watala National Park and Allied areas of District Bhimber AJK

\begin{tabular}{c|c}
\hline Species name & Frequency (\%) \\
\hline Butea monosperma & 29.5 \\
Dalbergia sissoo & 19.5 \\
Senegalia modesta & 11.25 \\
Grewia optiva & 10.25 \\
Ziziphus jujuba & 9.25 \\
Azadirachta indica & 8.5 \\
Calotropis procera & 7.75 \\
Ricinus communis & 2.25 \\
Datura inoxia & 1.75 \\
\hline
\end{tabular}




\section{Conclusion and future recommendations}

The research work of WNP is of paramount significance as this area is first time explored for ethnomedicinal (EMs) and ethnobotanical (EB) analysis and it has provided the detailed list of all plants of the area in checklist form. It also describes how local people of the area fulfil their daily life needs from indigenous plants and their traditional culture was also recorded in document form. Rural people of the area depend on tree species for shelter, fuel, households, fodder, shadow and food purposes. Butea monosperma, Grewia optiva, Carica opaca, Dalbergia sissoo, Bauhenia variegata, Senegalia modesta, Acacia nilotica and Mangifera indica are key species being used in multiple uses. Dalbergia sissoo, Butea monosperma and Mangifera indica are under severe threat due to microbial attack and anthropogenic activities. There is dare need to protect and devise ex-situ and in-situ conservation methods in order to keep the ecosystem of WNP in a sustainable form to cope with the primary needs of village communities, whose whole life depends on the biodiversity of the area. Many plants of the area have good medicinal potential and further ethnopharmacological research should be carried out for novel drug discovery and subsequent drug development and "green drugs" are better than allopathic medicines. It is inevitable to mention that participation and cooperation of indigenous communities is very paramount devoid of that all efforts will be futile and fruitless.

Acknowledgements. This research work is part of the first author's doctoral thesis work who (Ms Mehwish Maqbool) is highly obliged to Chairperson and Lab staff of the Department of Botany, Mirpur University of Science and Technology (MUST) Bhimber Campus Azad Jammu and Kashmir, Pakistan for their kind assistance in the Ph.D. research work conducted in field and lab. The first author is highly indebted to her supervisor Dr Muhammad Ajaib for his all-time coaching and gracious guidance in the completion of this part of her doctoral thesis.

\section{REFERENCES}

[1] Ahmad, I., Hussain, M., Ahmad, M. S. A., Hameed, M. (2008): Spatio-temporal effects on association of plant species in some valley of Pakistan. - Pak. J. Bot. 40: 1865-1867.

[2] Ajaib, M., Haider, S. K., Zikrea, A., Siddiqui, M. F. (2014a): Ethnobotanical studies of herbs of Agra Valley Parachinar, Upper Kurram Agency, Pakistan. - Int. J. Biol. Biotech. 11: 71-83.

[3] Ajaib, M., Zabta, K. S., Zikrea, A. (2014b): Ethnobotanical survey of some important herbaceous plants of District Kotli, Azad Jammu \& Kashmir. - Biologia (Pakistan) 60: 11-22.

[4] Ajaib, M., Anjum, M., Malik, N. Z., Siddique, M. F. (2015): Ethnobotanical study of some plants of Darguti Tehsil Khuiratta Azad Jammu and Kashmir. - Int. J. Biol. Res. 3(2): 101-107.

[5] Ajaib, M., Islam, A., Siddiqui, M. F. (2016): A contribution to ethnobotanical study of wild plants of Tehsil Jatlan Azad Jammu \& Kashmir. - FUUAST J. Biol. 6: 247-256.

[6] Alcorn, J. B. (1984): Development policy forests and peasant farms: reflection on Huastec-managed forests contributions to commercial production and resource conservation. - Econ. Bot. 38(4): 389-406.

[7] Ali, S. I., Qaiser, M. (eds.) (1993-2015): Flora of Pakistan. - Nos, Karachi.

[8] Ali, S. I., Omer, S., Qaiser, M. (2001): Flora of Pakistan. - In: Afzal, M., Mufti, S. A. (eds.) Natural History Research in Pakistan. PASTIC, Islamabad. 
[9] Altieri, M. A., Merick, L. C. (1987): In situ conservation of crop genetic resources through maintenance of traditional farming system. - Econ. Bot. 4(1): 86-96.

[10] Amjad, M. S., Qaeem. M. F., Ahmad, I., Khan, S., Chaudhari, S. K., Malik, N. Z., Shaheen, H., Khan, A. M. (2017): Description study of plant resources in the context of the ethnomedicinal relevance of indigenous flora: a case study from Toli Peer National Park, Azad Jammu and Kashmir, Pakistan. - J Plos One 12(2): 1-31.

[11] Alexiades, M. N. (1996): Selected Guidelines for Ethnobotanical Research: A Field Manual. - In: Advances in Economic Botany Vol. 10. The New York Botanical Garden, Bronx.

[12] Baheem, S. (1890): Tradition and History of Kashmir, Watala Area of District Bhimber Azad Kashmir. - Verinaag Publishers, Srinagar, Kashmir, pp. 110-145.

[13] Chassagne, F., Hul, S., Deharo, E., Bourdy, G. (2015): Natural remedies used by Bunong people in Mondulkiri province (Northeast Cambodia) with special reference to the treatment of 11 most common ailments. - J Ethnopharmacol. 191: 41-70. DOI: 10.1016/j.jep.2016.06.003.

[14] Cook, F. M. (1995): Economic Botany Data Collection Standard. - R. B. G., Kew.

[15] Dar, M. E. U. I., Gillani, N., Shaheen, H., Firdous, S. S., Ahmad, S., Khan, M. Q., Hussain, M. A., Habib, T. M. N. Z., Ullah, T. S., Rafique, S., Aziz, S., Khan, W. A., Hussain, K. (2018): Comparative analysis of vegetation from eroded and non-eroded areas, a case study from Kashmir Himalayas, Pakistan. - Applied Ecology and Environmental Research 16(2) 1725-1737.

[16] Erasto, P., Adebola, P. O., Grierson, D. S., Afolayan, A. J. (2005): An ethnobotanical study of plants used for the treatment of diabetes in the Eastern Cape Province, South Africa. - African Journal of Biotechnology 4(12): 1458-1460.

[17] Ford, R. I. (1978): Ethnobotany: Historical Diversity and Synthesis. - University of Michigan, Museum of Anthropology, Ann Arbor.

[18] Harshberger, J. W. (1896): The purpose of ethnobotany. - Bot. Gaz. 21: 146-158.

[19] Ishtiaq, M., Khan, M. A. (2008): An ethnopharmacological inventory of plants used in midwifery in Tehsil Samahni, District Bhimber Azad Kashmir, Pakistan. - Indian Journal of Traditional Knowledge 7(2) 277-283.

[20] Ishtiaq, M., Mir, A. K., Wajahat, H. (2006a): Ethnoveterinary medicinal uses of plants of from Samahni Valley District Bhimber, (Azad Kashmir) Pakistan. - Asian J. Pl. Sci. 5(2): 390-396.

[21] Ishtiaq, M., He, Q., Cheng, Y. Y., Xiao, P. G. (2006b): Ethnobotany of medicinal plants from Tian Mu Shan Biosphere Reserve, Zhejiang Province, China. - Asian J. of Pl. Sci 5(4): 646-653.

[22] Ishtiaq, M., Wajahat, H., Mir, A. K, Muhammad, A., Ansar, M. B. (2007a): An ethnomedicinal survey and documentation of important medicinal folklore food phytonyms of flora of Samahni Valley, (Azad Kashmir) Pakistan. - Pak. J. Biol. Sci. 10(13): 2241-2256.

[23] Ishtiaq, M., Qing, H., Xiao, P. G. Cheng, Y. Y. (2007b): Clematis huchouensis Tamura: a traditional Chinese Herbal medicine and its quality control using a high performance liquid chromatography technique. - Biol. Pharm. Bull. 30(1): 165-168.

[24] Ishtiaq, M., Mehwish, M., Tanveer, H. (2012): Interrelationship of cultural diversity and biodiversity and its impact on conservation. - Pak. J Bot. 44: 245-256.

[25] Ishtiaq, M., Mehwish, M., Tanveer, H., Amin, S. (2013a): Role of indigenous knowledge in biodiversity conservation of an area: a case study on tree ethnobotany of Soona valley, district Bhimber Azad Kashmir, Pakistan. - Pak J Bot 45(SI): 389-399.

[26] Ishtiaq, M., Pazeer, I., Tanveer, H. (2013b): Ethnomedicinal and economic uses of gymnosperms of Neelum Valley District Muzaffarabad Azad Kashmir Pakistan. - Ind J. of Trad Knowl. 12(3): 404-410. 
[27] Ishtiaq, M., Mehwish, M., Tanvir, H., Shehzad, A. (2016): Ethnomedico profile of indigenous flora of Tehsil Barnala District Bhimber Azad Jammu and Kashmir. - J. of Med. Pl. Stud. 3(2): 97-104.

[28] Jones, V. H. (1941): The nature and scope of ethnobotany. - Chronica Botanica 6: 21922.

[29] Martin, J. (1995): Ethnobotany: A Method Manual, People and Plants Conservation Manual. - Champman and Hall, London.

[30] Mahmood, A, Mahmood, A., Malik, R. N. (2012): Indigenous knowledge of medicinal plants from Leepa valley, Azad Jammu and Kashmir, Pakistan. - J Ethnopharmacol. 143(1): 338-46.

[31] Mcdichen, K. G., Mehl, C. B. (1990): Farmer Prospective of Improvement Objective of MPTS. - In: Glover, N., Adams, N. (eds.) Improvement of Multiple-Purpose Species. Tech-Services Vol. 2. Winrock Instt. for Inter Development and USAID, Little Rock, AR, pp. 50-56.

[32] Meza, P. L., Villagran, C. (1991): Ethnobotany of Alao Island, Chile. - Mus Nac His Nat Bol. (Santiago) 42: 39-78.

[33] Nadeem, A., A. Mehmood, S. Adeel, S. Tahir, B. Asghari, Rifat, N. M. Seema, H., Ishtiaq, M. (2014): Relative importance of indigenous medicinal plants from Layyah district, Punjab Province, Pakistan. - J Ethnopharm 155(1): 509-523.

[34] Naseem, H., Ahsan, M., Shahid, M. A., Khan, N. (2018): Exopolysaccharides producing rhizobacteria and their role in plant growth and drought tolerance. - Basic Microbiol. 58(12): 1009-1022.

[35] Nasir, E., Ali, S. I. (eds.) (1970-1989): Flora of Pakistan. - Islamabad, Karachi.

[36] Okuthe, O. S., McLeod, A., Otte, J. M., Buyu, G. E. (2003): Use of rapid rural appraisal and cross-sectional studies in the assessment of constraints in smallholder cattle production systems in the western Kenya highlands. - Onderstepoort J Vet Res. 70(3):237-42.

[37] Pei, S. (1995): Ethnobotany and sustainable use of plant resource in the HKH mountain region. Proceedings of the Planning Workshop on Ethnobotany and Its Application to Conservation and Community Development in the Hindu Kush Himalayan (HKH) Region. - Biol. Conser. 63(3): 205-210.

[38] Qamar, Q. Z. (1996): Status of major wildlife species and their management in Ghamot game reserve Neelum Valley, District Muzaffarabad. - M.Sc. Thesis submitted to the University of AJK, Muzaffarabad.

[39] Sher, H., Bussmann, R. W., Hart, R, de Boer, H. J. (2016): Traditional use of medicinal plants among Kalasha, Ismaeli and Sunni groups in Chitral District, Khyber Pakhtunkhwa province, Pakistan. - J Ethnopharmacol.188: 57-69. DOI: 10.1016/j.jep.2016.04.059.

[40] Shinwari, M. I., Khan, M. A. (2000): Folk use of medicinal herbs at Margalla Hills National Park, Islamabad. - Journal of Ethnopharmacology 69: 45-65.

[41] Umair, M., Altaf, M, Abbasi, A. M. (2017): An ethnobotanical survey of indigenous medicinal plants in Hafizabad District, Punjab, Pakistan. - PLoS One 12(6): e0177912. DOI: 10.1371/journal.pone.0177912.

[42] Vijayakumar, S., Yabesh, J. M., Prabhu, S., Manikandan, R., Muralidharan, B. (2015): Quantitative ethnomedicinal study of plants used in the Nelliyampathy hills of Kerala, India. - J. Ethnopharma. 161: 238-254.

[43] Vitalini, S., Iriti, M., Puricelli, C., Ciuchi, D., Segale, A., Fico, G. (2012): Traditional knowledge on medicinal and food plants used in ValSan Giacomo (Sondrio, Italy) an alpine ethnobotanical study. - J. Ethnopharma. 145: 517-529. 